\title{
Comprehensive evaluation of water resources security in the Yellow River basin based on a fuzzy multi-attribute decision analysis approach
}

\author{
K. K. Liu ${ }^{1,2}$, C. H. Li ${ }^{1}$, Y. P. Cai ${ }^{3,4}$, M. Xü ${ }^{1}$, and X. H. Xia ${ }^{1}$ \\ ${ }^{1}$ Ministry of Education Key Laboratory of Water and Sediment Sciences, School of Environment, Beijing Normal University, \\ Beijing, 100875, China \\ ${ }^{2}$ CERI eco Technology Co., LTD, Beijing, 100053, China \\ ${ }^{3}$ State Key Laboratory of Water Environment Simulation, School of Environment, Beijing Normal University, \\ Beijing, 100875, China \\ ${ }^{4}$ Institute for Energy, Environment and Sustainable Communities, University of Regina, 120, 2 Research Drive, Regina, \\ Saskatchewan, S4S 7H9, Canada
}

Correspondence to: C. H. Li (chunhuili@bnu.edu.cn) and Y. P. Cai (yanpeng.cai@bnu.edu.cn)

Received: 9 December 2013 - Published in Hydrol. Earth Syst. Sci. Discuss.: 10 January 2014

Revised: - Accepted: 12 March 2014 - Published: 7 May 2014

\begin{abstract}
In this paper, a fuzzy multi-attribute decision analysis approach (FMADAA) was developed for supporting the evaluation of water resources security in nine provinces within the Yellow River basin. A numerical approximation system and a modified left-right scoring approach were adopted to cope with the uncertainties in the acquired information. Also, four conventional multi-attribute decision analysis (MADA) methods were implemented in the evaluation model for impact evaluation, including simple weighted addition (SWA), weighted product (WP), cooperative game theory (CGT) and technique for order preference by similarity to ideal solution (TOPSIS). Moreover, several aggregation methods including average ranking procedure, Borda and Copeland methods were used to integrate the ranking results, helping rank the water resources security in those nine provinces as well as improving reliability of evaluation results. The ranking results showed that the water resources security of the entire basin was in critical condition, including the insecurity and absolute insecurity states, especially in Shanxi, Inner Mongolia and Ningxia provinces in which water resources were lower than the average quantity in China. Hence, the improvement of water eco-environment statuses in the above-mentioned provinces should be prioritized in the future planning of the Yellow River basin.
\end{abstract}

\section{Introduction}

Water is a fundamental resource for sustainable development of human society. Also, it is a critical factor for maintaining natural ecosystems. Water conflicts between human and ecosystems are posing great challenges for maintaining sustainability of water resources at the watershed scale. Along with the increasing consumptions of water resources by multiple users, water security crisis becomes an emerging issue that is facing decision-makers in many regions. How can the water resources be effectively allocated among the multiple water users without causing damages on local ecosystems? A balance between human beings and ecosystems needs to be maintained based on the introduction of water security not only for human society but also for local ecosystems. The development of an effective method is thus desired to help evaluate water security and facilitate the management of water resources scarcity (Brown and Hilweil, 1987; Loucks, 2000; WWAP, 2002; Chen, 2004; Zhang, 2010).

Water resources security is a concept that was proposed in the late 20th century (Jiang, 2001; Jia et al., 2002; Zheng, 2003; Xia and Zhang, 2007). It is generally believed that at a certain stage of social and economic development, water supply that can ensure both the quality and quantity is able to meet the needs of human survival, social progress, and economic development and is able to maintain a good ecological 
environment on the basis of not exceeding the carrying capacity of water resources and water eco-environment. This implies the desire to safeguard sustainable economic and social development based on sustainable water resources utilization. The evaluation and insurance of water security are the core issues of sustainable water resources management. Conventionally, water resources supporting capacity is considered as a basic water security measure which can be adopted for supporting the establishment of an evaluationindicator system. At the same time, some scholars argue that water resources security's core point lies in the sustainability of water use. If water resources in a region can be used sustainably, then, its water can be considered safe. According to this theory, the indicator system can be established including targets, criteria and indicators. The evaluation can be carried on in accordance with the indicators in five aspects including water resources availabilities, water resources exploitation and utilization efficiencies, external eco-environment conditions, water resources deployment conditions, and ability in managing water resources (Jia and Zhang, 2003; Zhang and Jia, 2003; Jia et al., 2004; Zhang et al., 2005, 2008).

At the same time, many evaluation methods were developed for evaluating water resources sustainability, such as those based on statistic analysis, data envelopment analysis, principal components analysis, system dynamics method, "pressure-state-response" modeling, set pair analysis, vague set evaluation, fuzzy element model, water-poor exponential method, artificial neural networks, element analysis and so forth. Many scholars have applied these methods to many real-world cases (Han et al., 2001; Cong, 2007; Zhu et al., 2008). Because the uncertain factors in the indicator system have great influences on the scientificity of evaluation, in order to deal with non-linear optimization of the evaluation process, the expression of implicit functions, fuzzy and random problems, the uncertainty evaluation methods and intelligent methods of integrated assessment methods gradually emerged. Among those methods, fuzzy multi-attribute decision analysis approach (FMADAA) was one of the effective methods for multiple-criteria decision support. For example, it was adopted in a landfill selection problem in the city of Regina and was considered as a powerful tool for decision analysis. More recently, it has been rapidly developed in numerous fields such as management, engineering, and so on (Buede, 1996; Eom, 1999; Yu et al., 2004; Cai et al., 2009; Parviz and Saeed, 2010; George and Mike, 2011; Harrison et al., 2011; Ana et al., 2012).

In the last two decades, the amount of water resources has decreased significantly in the Yellow River basin of China. The problem of water shortage has become extremely serious ( $\mathrm{Li}$ et al., 2004; Shen and Li, 2009; Li and Yang, 2004). Besides, water supply can not sufficiently meet the needs of industry, agriculture, residential and ecological sectors, which has made water security a particularly prominent problem affecting the economical and social development in the basin. In recent years, many scholars put their effort on the calculation of the supplied water quantity and requirement in order to analyze water utilization and water allocation (Xia et al., 2009) in order to provide support for water resources management in the Yellow River basin. However, a few researchers have carried out comprehensive water security evaluation in the Yellow River basin, especially in the analysis on the regional differences of the entire basin, which is important to the management in the basin. Therefore, the security evaluation in administrative regions of the basin is extremely necessary in order to promote the overall water resources security and to guarantee the coordinated development in the basin.

Since MADA aims to identify optimal alternatives for decision-makers, it is effective in supporting relevant decision-making processes. That is to say, various alternatives can be ranked according to certain criteria. Each region of the Yellow River basin can be considered as an alternative and each evaluation method can be considered as a criterion or an attribute. Also, in order to reflect uncertainties associated with the process, FMADAA needs to be adopted. It is suitable for evaluating water resources security in the Yellow River basin. Moreover, since the ranking results of different methods are inconsistent in practical application, the results will also be integrated, which could enhance applicability and accuracy of the results. In addition, fuzzy information usually encountered in practical evaluation processes can also be dealt with. Therefore, in the paper, we will adopt FMADAA to carry on the water resources security evaluation in the Yellow River basin in order to provide support for water management in the basin.

\section{Overview of the Yellow River basin}

The Yellow River is the second longest river in China. In total, the river flows over $5400 \mathrm{~km}$, passing through nine provinces and autonomous regions. As the biggest basin in northwest and North China, the Yellow River basin is of utmost importance for China in terms of food production, natural resources, and socioeconomic development. The Yellow River basin covers an approximately 0.752 million $\mathrm{km}^{2}$ area (not including inland), accounting for eight percent of the total area of China. Most areas of the Yellow River basin are in arid, semi -arid, and semi-humid climate zones, and it is one of the regions in China with the least water (Fig. 1). Affected by human activities and climate change, the Yellow River water resource has decreased significantly in recent years. Hence, water security problems, especially the disparity between supply and demand of water, and the gradual deterioration of the water eco-environment are particularly prominent and seriously affect economic and social development. Meanwhile, future climate change may further exacerbate regional droughts and floods, affecting the water supply and security of the Yellow River. 


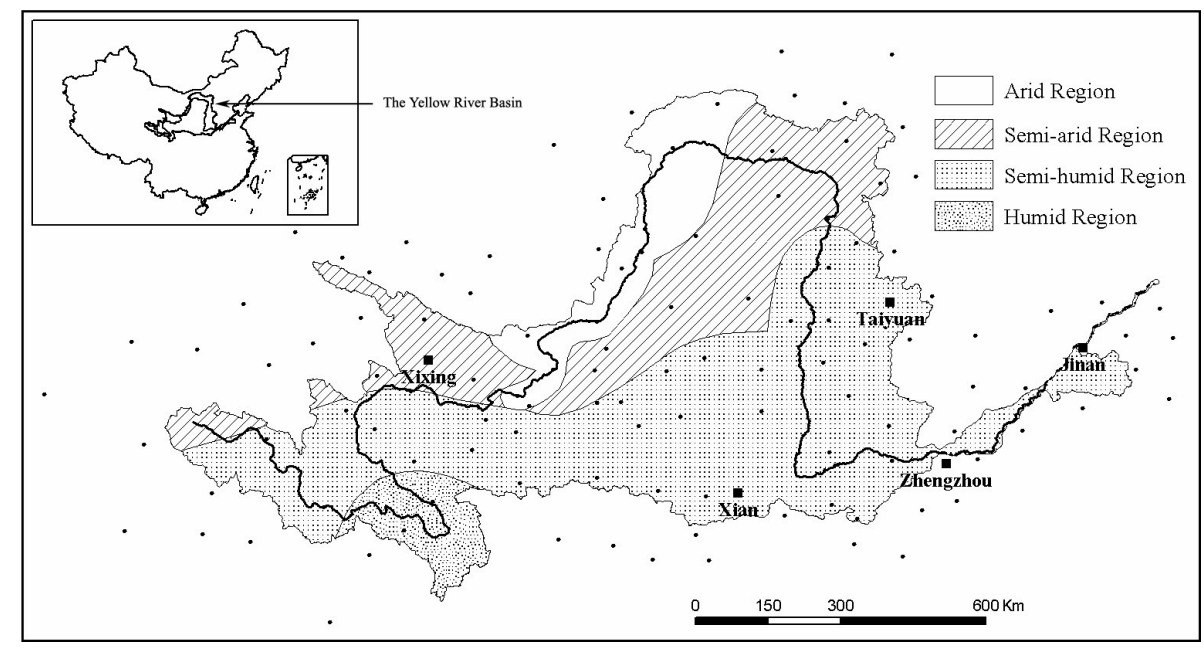

Fig. 1. The Yellow River basin.

Considering the data availability, we selected 2006 to be the evaluation year to analyze the current situation of water resources security in the Yellow River basin. Meanwhile, the data are derived from "Comprehensive Planning in the Yellow River Basin" (Yellow River Conservancy Committee of the Ministry of Water Resources, YRCC, MWR, 2009), "Water Resources Comprehensive Planning in the Yellow River Basin" (Yellow River Conservancy Committee of the Ministry of Water Resources, YRCC, MWR, 2009), related materials and statistical yearbook of the Yellow River (Yellow River Conservancy Committee of the Ministry of Water Resources, YRCC, MWR, 2006).

\section{Development of a water security evaluation system}

\subsection{Evaluation indicators}

We established the "pressure-state-response" water resources security evaluation model system which covered the indicators reflecting the water security situation in the Yellow River basin. "Pressure" system refers to those resources and social and economic factors which may cause pressure on the system, where the indicators are the decisive factors of the security of system. "State" system is the system status under the action of resources and social and economic indicators. "Response" system refers to the sensitivity and adaptability of the system to the actions of resources and social and economic indicators as well as the various measures taken to decrease the aggravation of water resources security. Each sub-system is established from three aspects, including water resources, socio-economic and water environment (Jia et al., 2002).

The indicator selection methods used in this paper contain a frequency statistical method, theoretical analysis and expert consultation (Delphi method). Based on the feedback from experts, a fuzzy analytic hierarchy process (FAHP) is adopted as the system analysis method to determine the water security evaluation indicator system (Zhang, 2000). Hence, the indicator system can be established, with the connotations and calculations of indicators shown in Table 1.

The evaluation criteria of the Yellow River basin has only a relative sense; we took the national data as a benchmark to set the evaluation criteria. The main references for determining the criteria mainly include the statistical data, relevant standards, norms, procedures, development plan, existing research results and so forth. In this paper, five interval evaluation criteria have been formulated, followed by absolute security, security, critical security, insecurity and absolute insecurity. Based on the evaluation criteria, the standards of the evaluation system were determined, which are shown in Table 2. A fuzzy analytic hierarchy process (FAHP) is adopted to determine the weights of indicators, and the calculation steps are the same as in the establishment of the water resources security evaluation indicator system. The weights of indicators were also obtained, which are shown in Table 3.

\subsection{Fuzzy multi-attribute decision analysis approach}

A fuzzy multi-attribute decision analysis approach (FMADAA) is applied for security evaluation. The proposed FMADAA is composed of four phases. In the first phase, the evaluation alternatives should be established. The second phase is fuzzy impact transformation, which consists of two major steps: (1) linguistic-term conversion that transforms the impact values into a fuzzy set if they are verbal terms; and (2) conversion from a fuzzy set to a crisp value set where all the fuzzy sets are assigned crisp scores. The result of this phase is to produce a new impact matrix that only contains numeric data. In the third phase, classical MADM methods can be utilized to determine the ranking order of alternatives. Finally, in the fourth phase, when the results of different 
Table 1. Water resources security evaluation indicator.

\begin{tabular}{|c|c|c|c|c|c|c|c|}
\hline \multicolumn{4}{|c|}{ Evaluation indicator } & \multirow{2}{*}{$\begin{array}{l}\text { Calculation formula } \\
\text { Total amount of water } \\
\text { resources/precipitation }\end{array}$} & \multirow[t]{2}{*}{ Indicator unit } & \multirow{2}{*}{$\begin{array}{l}\text { Indicator meaning } \\
\begin{array}{l}\text { Reflect the amount } \\
\text { of water resources }\end{array}\end{array}$} & \multirow{2}{*}{$\begin{array}{l}\text { Indicator } \\
\text { type }\end{array}$} \\
\hline $\begin{array}{l}\text { Pressure } \\
\text { indicators }\end{array}$ & & D1 & $\begin{array}{l}\text { Water production } \\
\text { coefficient }\end{array}$ & & & & \\
\hline \multirow[t]{10}{*}{ B1 } & & D2 & Annual runoff & $\begin{array}{l}\text { Regional runoff/ } \\
\text { evaluation area }\end{array}$ & $\mathrm{mm}$ & $\begin{array}{l}\text { Reflect the amount } \\
\text { of water resources }\end{array}$ & positive \\
\hline & Water resources & D3 & $\begin{array}{l}\text { Modulus of } \\
\text { groundwater } \\
\text { resources }\end{array}$ & $\begin{array}{l}\text { Groundwater resources } \\
\text { amount/evaluation area }\end{array}$ & $10^{4} \mathrm{~m}^{3} \mathrm{~km}^{-2}$ & $\begin{array}{l}\text { Reflect the amount } \\
\text { of groundwater } \\
\text { resources }\end{array}$ & positive \\
\hline & $\begin{array}{l}\text { pressure indicators } \\
\mathrm{C} 1\end{array}$ & D4 & $\begin{array}{l}\text { Modulus of water } \\
\text { resources }\end{array}$ & $\begin{array}{l}\text { Total amount of water } \\
\text { resources/evaluation area }\end{array}$ & $10^{4} \mathrm{~m}^{3} \mathrm{~km}^{-2}$ & $\begin{array}{l}\text { Reflect the amount } \\
\text { of water resources }\end{array}$ & positive \\
\hline & & D5 & $\begin{array}{l}\text { Water utilization } \\
\text { rate }\end{array}$ & $\begin{array}{l}\text { Water consumption } \\
\text { amount with the exception } \\
\text { of eco-environmental } \\
\text { water consumption/total } \\
\text { amount of water } \\
\text { resources } \times 100 \%\end{array}$ & $\%$ & $\begin{array}{l}\text { Reflect the } \\
\text { development and } \\
\text { utilization of water } \\
\text { resources }\end{array}$ & negative \\
\hline & $\begin{array}{l}\text { Socio-economic } \\
\text { pressure } \\
\text { indicators } \\
\mathrm{C} 2\end{array}$ & D6 & $\begin{array}{l}\text { Development } \\
\text { degree of surface } \\
\text { water }\end{array}$ & $\begin{array}{l}\text { Exploitation amount of } \\
\text { surface water/surface } \\
\text { water resources amount }\end{array}$ & $\%$ & $\begin{array}{l}\text { Reflect the } \\
\text { development and } \\
\text { utilization of surface } \\
\text { water resources }\end{array}$ & negative \\
\hline & & D7 & $\begin{array}{l}\text { Development } \\
\text { degree of } \\
\text { groundwater }\end{array}$ & $\begin{array}{l}\text { Exploitation amount of } \\
\text { groundwater/groundwater } \\
\text { resources amount }\end{array}$ & $\%$ & $\begin{array}{l}\text { Reflect the } \\
\text { development and } \\
\text { utilization of } \\
\text { groundwater } \\
\text { resources }\end{array}$ & negative \\
\hline & & D8 & $\begin{array}{l}\text { Water consumption } \\
\text { per } 10000 \text { Yuan } \\
\text { of GDP }\end{array}$ & $\begin{array}{l}\text { Total amount of water } \\
\text { consumption/GDP }\end{array}$ & $\begin{array}{l}\mathrm{m}^{3} / 10000 \\
\text { Yuan }\end{array}$ & $\begin{array}{l}\text { Reflect the } \\
\text { economic water } \\
\text { consumption level }\end{array}$ & negative \\
\hline & & D9 & $\begin{array}{l}\text { Water consumption } \\
\text { per } 10000 \text { Yuan } \\
\text { of industrial output }\end{array}$ & $\begin{array}{l}\text { Total amount of water } \\
\text { consumption/industrial } \\
\text { output }\end{array}$ & $\begin{array}{l}\mathrm{m}^{3} / 10000 \\
\text { Yuan }\end{array}$ & $\begin{array}{l}\text { Reflect the } \\
\text { economic water } \\
\text { consumption level }\end{array}$ & negative \\
\hline & $\begin{array}{l}\text { Water environment } \\
\text { pressure } \\
\text { indicators } \\
\text { C3 }\end{array}$ & D10 & $\begin{array}{l}\text { Ratio of pollutants } \\
\text { (COD and } \\
\text { ammonia } \\
\text { nitrogen) dumped } \\
\text { into the river }\end{array}$ & $\begin{array}{l}\text { Pollutants (COD and } \\
\text { ammonia nitrogen) } \\
\text { amount/annual runoff }\end{array}$ & $\mathrm{t} / 10^{4} \mathrm{~m}^{3}$ & $\begin{array}{l}\text { Reflect the } \\
\text { discharge condition } \\
\text { of the contaminants } \\
\text { from the waste } \\
\text { water }\end{array}$ & negative \\
\hline & & D11 & $\begin{array}{l}\text { Area ratio of } \\
\text { excessive } \\
\text { extraction of } \\
\text { groundwater }\end{array}$ & $\begin{array}{l}\text { Excessive extraction area } \\
\text { of groundwater (depression } \\
\text { funnel)/evaluation } \\
\text { area } \times 100 \%\end{array}$ & $\%$ & $\begin{array}{l}\text { Reflect the } \\
\text { excessive extraction } \\
\text { condition of } \\
\text { groundwater }\end{array}$ & negative \\
\hline \multirow[t]{5}{*}{$\begin{array}{l}\text { State } \\
\text { indictors } \\
\text { B2 }\end{array}$} & $\begin{array}{l}\text { Water resources } \\
\text { state indicators } \\
\text { C4 }\end{array}$ & D12 & $\begin{array}{l}\text { Index of water } \\
\text { resources } \\
\text { demand-supply } \\
\text { balance (IWDS) }\end{array}$ & $\begin{array}{l}\text { Average water demand } \\
\text { amount/water supply } \\
\text { amount }\end{array}$ & & $\begin{array}{l}\text { Reflect the water } \\
\text { demand-supply } \\
\text { balance condition }\end{array}$ & negative \\
\hline & & D13 & $\begin{array}{l}\text { Water resources } \\
\text { amount per capita }\end{array}$ & $\begin{array}{l}\text { Total amount of water } \\
\text { resources/total population }\end{array}$ & $\mathrm{m}^{3} /$ person & $\begin{array}{l}\text { Reflect the amount } \\
\text { of water resources } \\
\text { and water scarcity } \\
\text { condition }\end{array}$ & positive \\
\hline & $\begin{array}{l}\text { Socio-economic } \\
\text { state }\end{array}$ & D14 & $\begin{array}{l}\text { Water supply } \\
\text { modulus }\end{array}$ & $\begin{array}{l}\text { Water consumption } \\
\text { amount/evaluation area }\end{array}$ & $10^{4} \mathrm{~m}^{3} \mathrm{~km}^{-2}$ & $\begin{array}{l}\text { Reflect the intensity } \\
\text { of water supply }\end{array}$ & positive \\
\hline & $\begin{array}{l}\text { indicators } \\
\text { C5 }\end{array}$ & D15 & $\begin{array}{l}\text { Water supply } \\
\text { amount per capita }\end{array}$ & $\begin{array}{l}\text { Water consumption } \\
\text { amount/total population }\end{array}$ & $\mathrm{m}^{3} /$ person & $\begin{array}{l}\text { Reflect the intensity } \\
\text { of water supply }\end{array}$ & positive \\
\hline & & D16 & GDP per capita & GDP/total population & $\begin{array}{l}10000 \text { Yuan/ } \\
\text { person }\end{array}$ & $\begin{array}{l}\text { Reflect the overall } \\
\text { economic condition }\end{array}$ & positive \\
\hline
\end{tabular}


Table 1. Continued.

\begin{tabular}{|c|c|c|c|c|c|c|c|}
\hline \multicolumn{4}{|c|}{ Evaluation indicator } & \multirow{2}{*}{$\begin{array}{l}\text { Calculation formula } \\
\text { Agricultural water } \\
\text { consumption amount/ } \\
\text { water consumption } \\
\text { amount } \times 100 \%\end{array}$} & \multirow{2}{*}{$\begin{array}{l}\text { Indicator unit } \\
\%\end{array}$} & \multirow{2}{*}{$\begin{array}{l}\text { Indicator meaning } \\
\text { Reflect the } \\
\text { agricultural water } \\
\text { consumption level } \\
\text { and the structure of } \\
\text { water consumption }\end{array}$} & \multirow{2}{*}{$\begin{array}{l}\begin{array}{l}\text { Indicator } \\
\text { type }\end{array} \\
\text { negative }\end{array}$} \\
\hline & \multirow{7}{*}{$\begin{array}{l}\text { Water } \\
\text { eco-environment } \\
\text { state } \\
\text { indicators } \\
\text { C6 }\end{array}$} & D17 & $\begin{array}{l}\text { Ratio of } \\
\text { agricultural water } \\
\text { consumption to } \\
\text { total consumption }\end{array}$ & & & & \\
\hline & & D18 & $\begin{array}{l}\text { Domestic water } \\
\text { consumption per } \\
\text { capita }\end{array}$ & $\begin{array}{l}\text { Domestic water } \\
\text { consumption amount/total } \\
\text { population/365 }\end{array}$ & $\mathrm{L} /(\mathrm{d} \cdot$ person $)$ & $\begin{array}{l}\text { Reflect the living } \\
\text { water security } \\
\text { condition }\end{array}$ & positive \\
\hline & & D19 & $\begin{array}{l}\text { Eco-environment } \\
\text { water consumption } \\
\text { ratio }\end{array}$ & $\begin{array}{l}\text { Eco-environment water } \\
\text { consumption amount/total } \\
\text { population } \times 100 \%\end{array}$ & $\%$ & $\begin{array}{l}\text { Reflect the } \\
\text { eco-environment } \\
\text { water security } \\
\text { condition }\end{array}$ & positive \\
\hline & & D20 & $\begin{array}{l}\text { Ratio of soil } \\
\text { erosion area to the } \\
\text { total area }\end{array}$ & $\begin{array}{l}\text { Soil erosion area/ } \\
\text { evaluation area } \times 100 \%\end{array}$ & $\%$ & $\begin{array}{l}\text { Reflect the soil } \\
\text { erosion condition }\end{array}$ & negative \\
\hline & & D21 & $\begin{array}{l}\text { Up-to-standard rate } \\
\text { of water quality in } \\
\text { water function } \\
\text { area }\end{array}$ & $\begin{array}{l}\text { Number of up-to-standard } \\
\text { water function area/total } \\
\text { number of water function } \\
\text { area } \times 100 \%\end{array}$ & $\%$ & $\begin{array}{l}\text { Reflect the water } \\
\text { quality condition in } \\
\text { the function area }\end{array}$ & positive \\
\hline & & D22 & $\begin{array}{l}\text { Ratio of } \\
\text { up-to-standard } \\
\text { river length of } \\
\text { water quality to the } \\
\text { total river length }\end{array}$ & $\begin{array}{l}\text { Up-to-standard river } \\
\text { length of water quality/ } \\
\text { total evaluation river } \\
\text { length } \times 100 \%\end{array}$ & $\%$ & $\begin{array}{l}\text { Reflect the river } \\
\text { water quality } \\
\text { condition }\end{array}$ & positive \\
\hline & & D23 & $\begin{array}{l}\text { Ratio of class I, } \\
\text { II and III } \\
\text { groundwater area } \\
\text { of water quality to } \\
\text { the total area }\end{array}$ & $\begin{array}{l}\text { Class I, II and III } \\
\text { groundwater area of water } \\
\text { quality/total evaluation } \\
\text { area } \times 100 \%\end{array}$ & $\%$ & $\begin{array}{l}\text { Reflect the } \\
\text { groundwater quality } \\
\text { condition }\end{array}$ & positive \\
\hline \multirow[t]{6}{*}{$\begin{array}{l}\text { Response } \\
\text { indictors } \\
\text { B3 }\end{array}$} & $\begin{array}{l}\text { Socio-economic } \\
\text { response } \\
\text { indicators } \\
\mathrm{C} 7\end{array}$ & D24 & $\begin{array}{l}\text { Water conservancy } \\
\text { investment rate }\end{array}$ & $\begin{array}{l}\text { Water conservancy } \\
\text { investment amount/ } \\
\text { GDP } \times 100 \%\end{array}$ & $\%$ & $\begin{array}{l}\text { Reflect the water } \\
\text { conservancy } \\
\text { investment } \\
\text { condition }\end{array}$ & positive \\
\hline & & D25 & $\begin{array}{l}\text { Industrial water } \\
\text { re-utilization rate }\end{array}$ & $\begin{array}{l}\text { Industrial water } \\
\text { re-utilization amount/ } \\
\text { industrial water } \\
\text { consumption } \\
\text { amount } \times 100 \%\end{array}$ & $\%$ & $\begin{array}{l}\text { Reflect the } \\
\text { industrial } \\
\text { water-saving } \\
\text { condition }\end{array}$ & positive \\
\hline & & D26 & $\begin{array}{l}\text { Effective irrigation } \\
\text { coverage rate }\end{array}$ & $\begin{array}{l}\text { Effective irrigation } \\
\text { area/cultivated land } \\
\text { area } \times 100 \%\end{array}$ & $\%$ & $\begin{array}{l}\text { Reflect the } \\
\text { irrigation level }\end{array}$ & positive \\
\hline & & D27 & $\begin{array}{l}\text { Water irrigation } \\
\text { efficiency }\end{array}$ & $\begin{array}{l}\text { Field water consumption } \\
\text { amount/water intake } \\
\text { amount in the field }\end{array}$ & & $\begin{array}{l}\text { Reflect the quality } \\
\text { of the irrigation } \\
\text { project, the level of } \\
\text { irrigation } \\
\text { technology and the } \\
\text { water irrigation } \\
\text { management } \\
\text { condition }\end{array}$ & positive \\
\hline & & D28 & $\begin{array}{l}\text { Water-saving } \\
\text { irrigation rate }\end{array}$ & $\begin{array}{l}\text { Water-saving irrigation } \\
\text { area/effective irrigation } \\
\text { area } \times 100 \%\end{array}$ & $\%$ & $\begin{array}{l}\text { Reflect the } \\
\text { irrigation } \\
\text { water-saving } \\
\text { condition }\end{array}$ & positive \\
\hline & & D29 & $\begin{array}{l}\text { Leakage rate of } \\
\text { water supply pipe } \\
\text { network }\end{array}$ & $\begin{array}{l}\text { (Urban water supply } \\
\text { amount }- \text { effective water } \\
\text { supply amount)/urban } \\
\text { water supply } \\
\text { amount } \times 100 \%\end{array}$ & $\%$ & $\begin{array}{l}\text { Reflect the urban } \\
\text { water-saving } \\
\text { condition }\end{array}$ & negative \\
\hline
\end{tabular}


Table 1. Continued.

\begin{tabular}{|c|c|c|c|c|c|}
\hline \multicolumn{2}{|c|}{ Evaluation indicator } & \multirow{2}{*}{$\begin{array}{l}\text { Calculation formula } \\
\text { Water-saving appliances } \\
\text { penetration families/total } \\
\text { families } \times 100 \%\end{array}$} & \multirow{2}{*}{$\begin{array}{l}\text { Indicator unit } \\
\%\end{array}$} & \multirow{2}{*}{$\begin{array}{l}\text { Indicator meaning } \\
\text { Reflect the urban } \\
\text { water-saving } \\
\text { condition }\end{array}$} & \multirow{2}{*}{$\begin{array}{l}\begin{array}{l}\text { Indicator } \\
\text { type }\end{array} \\
\text { positive }\end{array}$} \\
\hline D30 & $\begin{array}{l}\text { Water-saving } \\
\text { appliances } \\
\text { penetration rate }\end{array}$ & & & & \\
\hline D31 & $\begin{array}{l}\text { Ratio of urban } \\
\text { population access } \\
\text { to up-to-standard } \\
\text { drinking water to } \\
\text { the total urban } \\
\text { population }\end{array}$ & $\begin{array}{l}\text { Urban population access to } \\
\text { up-to-standard drinking } \\
\text { water/total urban } \\
\text { population } \times 100 \%\end{array}$ & $\%$ & $\begin{array}{l}\text { Reflect the urban } \\
\text { drinking water } \\
\text { condition }\end{array}$ & positive \\
\hline D32 & $\begin{array}{l}\text { Ratio of rural } \\
\text { population access } \\
\text { to up-to-standard } \\
\text { drinking water to } \\
\text { the total rural } \\
\text { population }\end{array}$ & $\begin{array}{l}\text { Rural population access to } \\
\text { up-to-standard drinking } \\
\text { water/total rural } \\
\text { population } \times 100 \%\end{array}$ & $\%$ & $\begin{array}{l}\text { Reflect the rural } \\
\text { drinking water } \\
\text { condition }\end{array}$ & positive \\
\hline D33 & $\begin{array}{l}\text { Perfection degree } \\
\text { of management } \\
\text { system and legal } \\
\text { system }\end{array}$ & $\begin{array}{l}\text { Management system and } \\
\text { legal system }\end{array}$ & & $\begin{array}{l}\text { Reflect the water } \\
\text { resources } \\
\text { management } \\
\text { condition }\end{array}$ & positive \\
\hline
\end{tabular}

MADM methods are inconsistent, a further aggregation is needed.

In this paper, nine provinces in the Yellow River basin and evaluation criteria constituted the alternatives. Then the numerical approximation system and the modified left-right scoring approach were adopted to cope with the uncertainties in the acquired information. Four commonly used multi-attribute decision-making (MADM) methods were implemented in the evaluation model for impact evaluation, including the simple weighted addition (SWA) method, weighted product (WP) method, cooperative game theory (CGT) method and technique for order preference by similarity to ideal solution (TOPSIS) method. These MADM methods helped to rank the nine provinces and the criteria alternatives, and three aggregation methods, including average ranking procedure, Borda and Copeland methods, were used to integrate the ranking results. The details of the four phases are listed below.

\subsubsection{Alternatives establishment}

First, the alternatives to be ranked in the MADM methods should be fixed. In this paper, the nine provinces in the Yellow River basin were considered to be the nine alternatives (see Fig. 2). Because the MADM method adopted in this paper is aimed to evaluate the water resources security of the Yellow River basin, the evaluation criteria should also be transformed into different alternatives in order to be compared with the security of the basin. Therefore, 13 criteria alternatives $A_{a}, A_{b}, A_{c}, A_{d}, A_{e}, A_{f}, A_{g}, A_{h}, A_{i}, A_{j}, A_{k}, A_{l}$ and $A_{m}$ were obtained here, among which $A_{a}, A_{e}, A_{i}$ and $A_{m}$ are critical values of the 5 interval criteria. In addition, three criteria alternatives were added between $A_{a}$ and $A_{e}, A_{e}$ and $A_{i}$, as well as $A_{i}$ and $A_{m}$, respectively. It is worth noting that the criteria alternatives can be selected according to different conditions or different evaluation purposes.

\subsubsection{Fuzzy impact transformation}

\section{(a) Linguistic-term conversion}

A numerical approximation system is proposed by Hwang and Chen (1992) to systematically transform linguistic terms to their corresponding fuzzy sets. According to Hwang, the transformation requires eight conversion scales. The conversion scales are proposed by synthesizing and modifying the work of Baas and Kwakemaak (1977), Bonissone (1982) and Chen (1988). It is assumed that the given figures can adequately cover all expressions of any specific feature -"high" vs. "low". One of the figures is employed when certain terms are provided and the principle is to simply select a scale figure that contains all the verbal terms given by the decisionmaker and use the membership function set for that figure to represent the meaning of the verbal terms. For example, if the given certain terms include "low", "medium" and "high", the scale shown in Fig. 3 is to be selected.

\section{(b) Conversion from fuzzy sets to crisp values}

A modified left-right scoring approach based on Jain's (1976, 1977) and Chen's (1985) works is introduced. In order to determine a crisp score, it is necessary to compare the fuzzy sets with a maximizing fuzzy set (fuzzy 


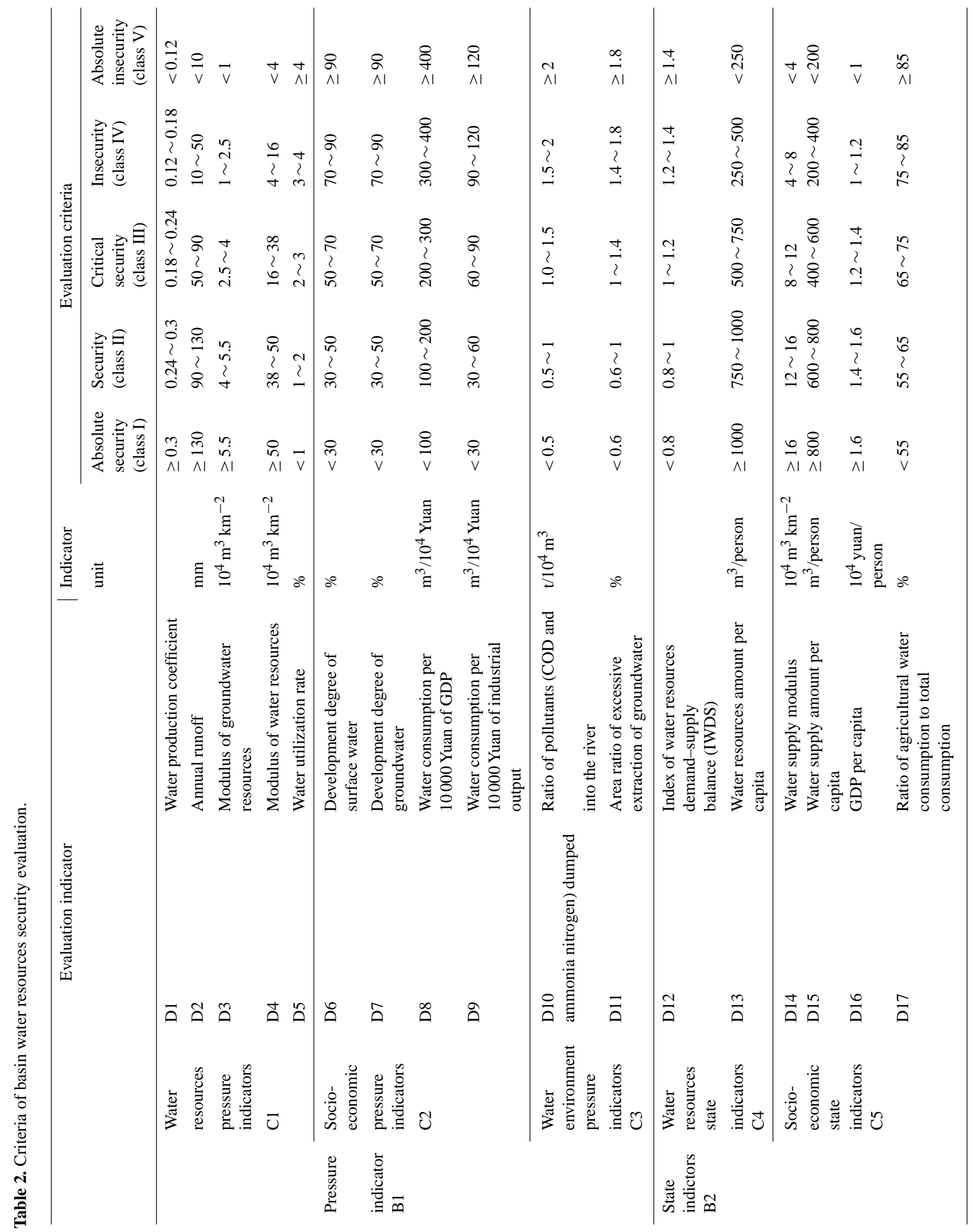




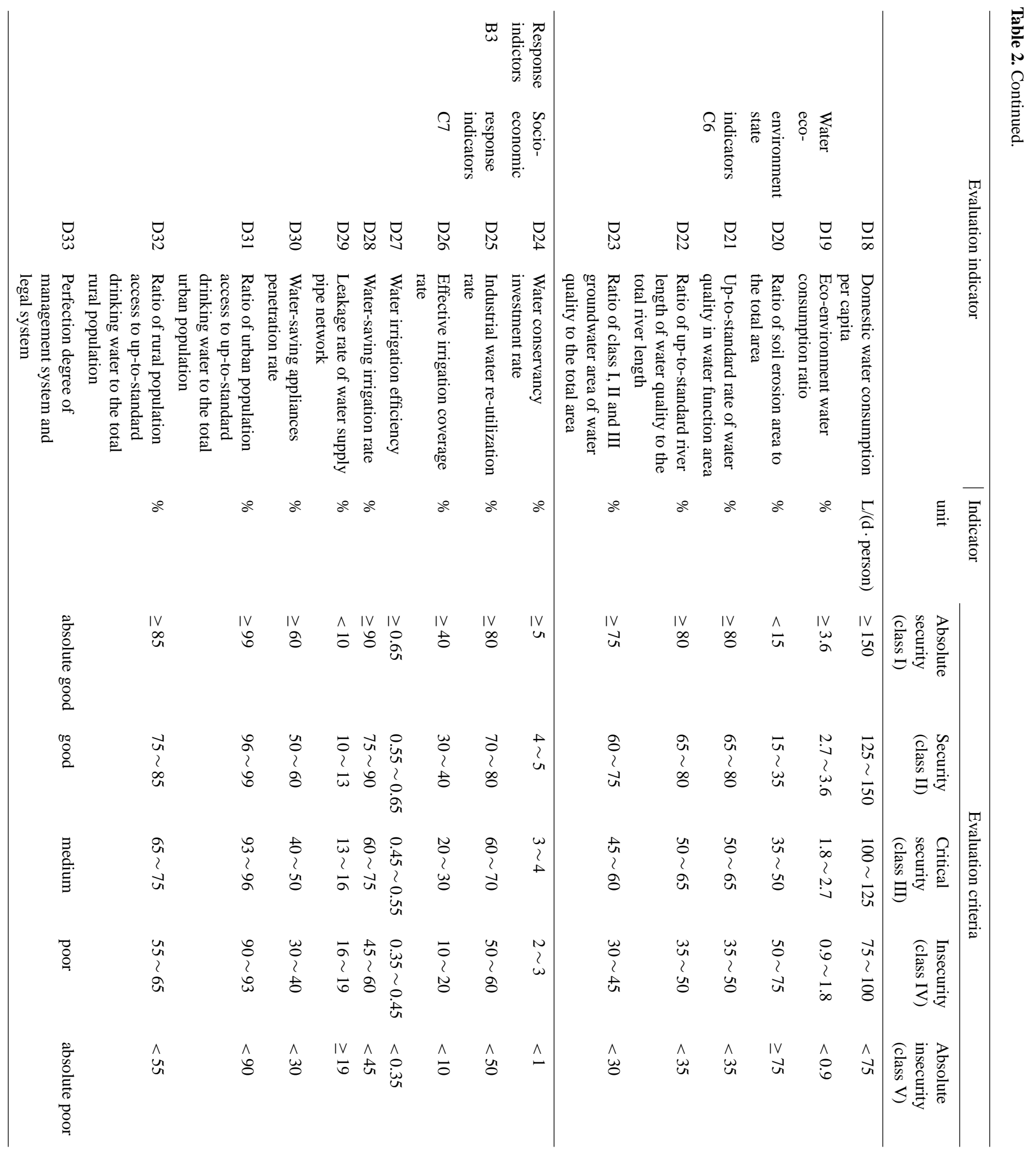


Table 3. Weights of water resources security evaluation indicator.

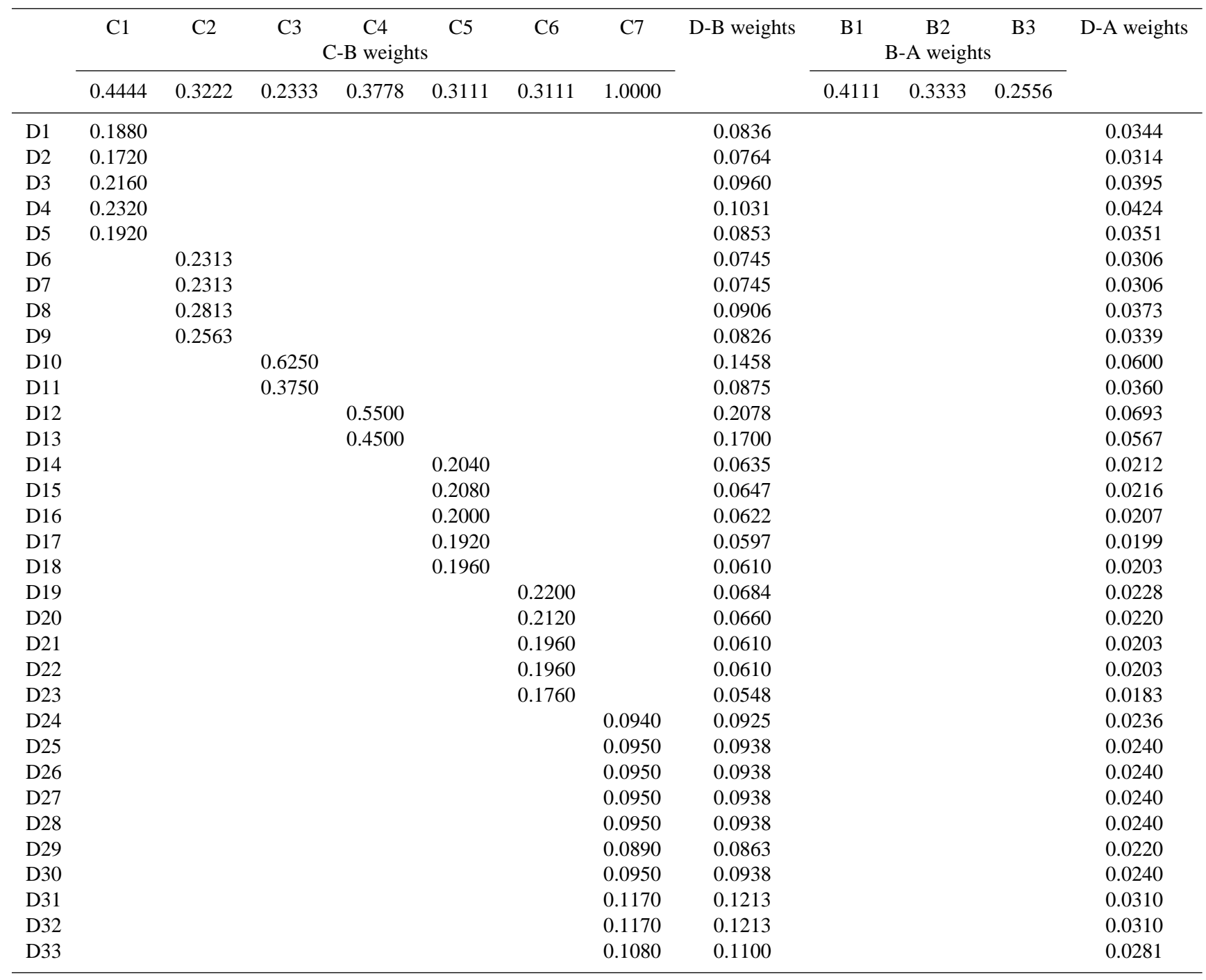

max) and a minimizing fuzzy set (fuzzy min) (Hwang and Chen, 1992). These two fuzzy sets are defined as

$\mu_{\max }(x)=\left\{\begin{array}{l}x, 0 \leq x \leq 1 \\ 0, \text { otherwise }\end{array}\right.$

$\mu_{\min }(x)=\left\{\begin{array}{l}1-x, \quad 0 \leq x \leq 1 \\ 0, \text { otherwise }\end{array}\right.$.

The right score refers to the intersections of the fuzzy set $M$ with max. The right score of $M$ can be determined using (see Fig. 3)

$\mu_{R}(M)=\sup _{x}\left[\mu_{M}(x) \wedge \mu_{\max }(x)\right]$.

Similarly, the left score of $M$ can be determined using

$\mu_{L}(M)=\sup _{x}\left[\mu_{M}(x) \wedge \mu_{\min }(x)\right]$.
Given the left and right scores of $M$, the total score of $M$ can be calculated using

$\mu_{T}(M)=\left[\mu_{R}(M)+1-\mu_{L}(M)\right] / 2$.

Consequently, the set of $\mu_{\text {total }}$ can substitute the original linguistic terms and impact matrix with only the crisp values that are formed.

\subsubsection{Multi-attribute decision-making (MADM) methods}

MADM methods are management decision aids in evaluating competing alternatives defined by multiple attributes. In this paper, four MADM methods are adopted in the evaluation system. The reason for applying these four methods is because they use the same type of input parameters, whereas other MADM methods use different ones. Before presenting 


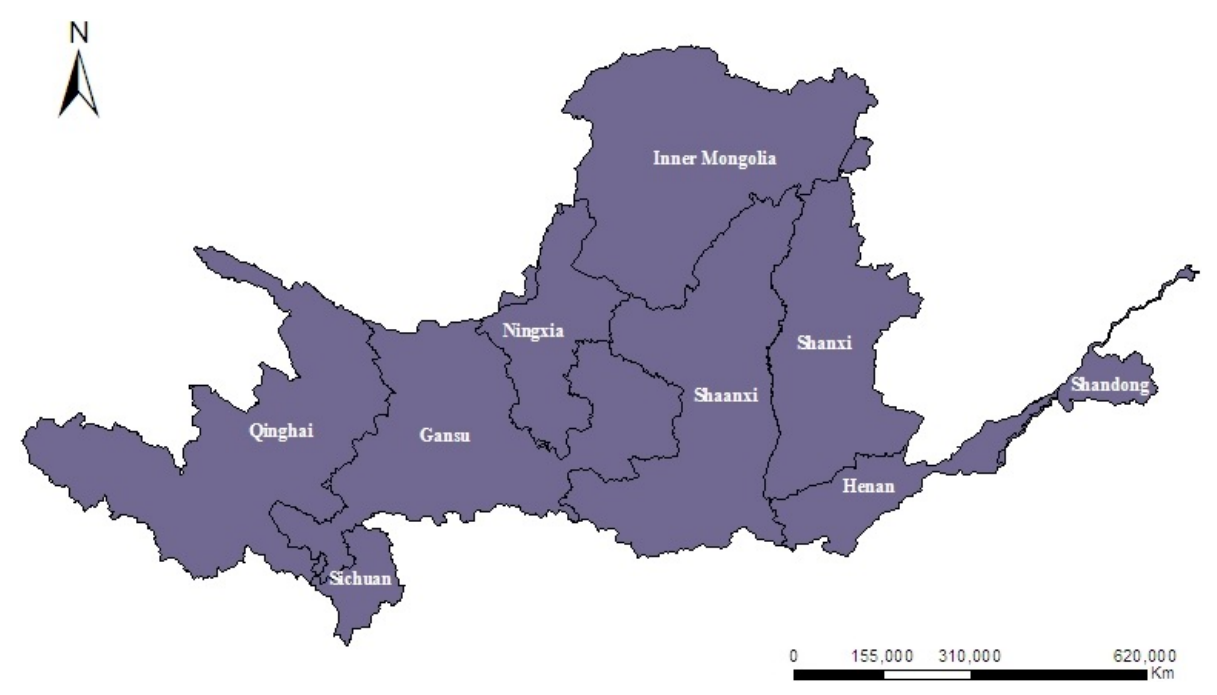

Fig. 2. Administrative regions to be evaluated in the Yellow River basin.

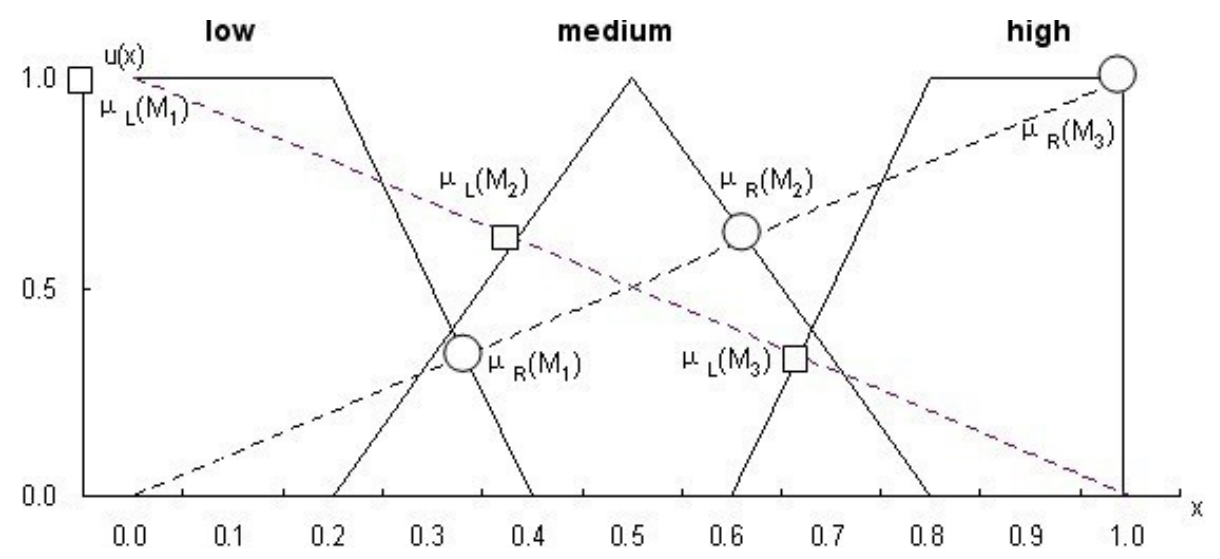

Fig. 3. One scale for the graph of membership function (Hwang and Chen, 1992).

the details of these methods, some basic concepts of decision weight and data normalization should be introduced.

Firstly, almost all MADM problems require information regarding the relative importance of each attribute, including the methods used in the evaluation system here. The relative importance is usually given by a set of weights which are standardized to a sum equal to 1 . Weight set is usually represented as follows:

$W^{T}=\left(w_{1}, w_{2}, \ldots, w_{n}\right)$

$\sum_{i=1}^{n} w_{i}=1$

where $n$ represents the number of attributes, $T$ represents a set of the traverse form, $W^{T}$ is a set of weights with $n$ attributes. The weights can be assigned by different methods (Saaty, 1977; Chu et al., 1979; Nijkamp et al., 1990). In this paper, FAHP is adopted as referred to above.
Then, according to Hwang and Yoon (1981), some methods such as SWA must apply the normalization method to normalize values in the impact matrix so that any effect introduced by different measurement units is neutralized. In the evaluation system, two ways of normalization are applied to cope with different MADM methods. The linear normalization adopted here is a modified process by Hwang and Yoon (1981). The normalized value $r_{i j}$ can be defined as follows:

for impact value of benefit attributes, $r_{i j}^{b}=\frac{x_{i j}-x_{i}^{\min }}{x_{i}^{*}-x_{i}^{\min }}$,

for impact values of cost attributes, $r_{i j}^{c}=\frac{x_{i}^{*}-x_{i j}}{x_{i}^{*}-x_{i}^{\min }}$,

where $x_{i}^{*}=\max _{j} x_{i j}$ and $x_{i}^{\min }$ is the least acceptable impact value of $i$ attribute. The worst outcome of a certain attribute implies $r_{i j}=0$, while the best outcome implies $r_{i j}=1$. The vector normalization divides the impact value of each 
attribute by its norm, so that each normalized value $r_{i j}$ can be calculated as

$r_{i j}=\frac{x_{i j}}{\sqrt{\sum_{j=1}^{m} x_{i j}^{2}}}$

where $m$ is the total number of alternatives. Several MADM methods will be adopted, including:

\section{(a) Simple weighted addition (SWA) method}

The SWA method is the simplest MADM method to handle cardinal data (Hwang and Yoon, 1981). Linear transformation is applied, which normalizes the impact matrix, and the utility function can be written as

$U_{j}=\sum_{i=1}^{n} w_{i} r_{i j}, j=1,2, \ldots, m$,

where $w_{i}$ is the importance weight of the attributes and $r_{i j}$ is the normalized impact matrix. The alternative with the highest score is the most preferable one. However, since complementarity often exists among attributes, the assumption of preferential independence may be unacceptable, and ignoring the dependence among attributes may cause a misleading result (Hwang and Chen, 1992).

\section{(b) Weighted product (WP) method}

The WP method was introduced long ago (Starr, 1972; Yoon, 1989) and normalization is not necessary (Yoon and Hwang, 1995). Formally, the utility value $U_{j}$ of each alternative is given by

$U_{j}=\prod_{i=1}^{n} x_{i j}^{w_{j}}, j=1,2, \ldots, m$,

where $w_{j}$ is the importance weight of the $i$ th attribute and $x_{i j}$ is the impact value of the $j$ th alternative. Similarly, the alternative with the largest utility value is considered the most preferable one to the decision-maker. Theoretically, the utility value may become infinite due to the characteristic of multiplication and the distance between the utility values of the most and second most preferable alternatives would be greater than that derived from the SWA method.

\section{(c) Cooperative game theory (CGT)}

Developed by Szidarovszky and Yakowitz (1978), and it is described as the hybrid of the WP and TOPSIS method. By using CGT, the decision-maker looks for a solution that would be as far away from the worst solution as possible. Therefore, the safety of the solution is guaranteed. To define a worst solution, one way is to use the worst impact value of each attribute. Given a set of non-dominant alternatives, the set of worst impact value, denoted as $A^{-}$, is defined as

$$
\begin{aligned}
A^{-} & =\left\{\left(\min _{j} x_{i j} \mid i \in I\right),\left(\max _{j} x_{i j} \mid i \in I^{*}\right) \mid j\right. \\
& =1,2, \cdots, m\}=\left\{x_{1}^{-}, x_{2}^{-}, \ldots, x_{i}^{-}, \ldots x_{n}^{-}\right\},
\end{aligned}
$$

where $x_{i j}$ is the impact value of attribute $i$ and $x_{i}^{-}$is considered as the worst outcome for each attribute. Once the worst solution is defined, the utility values $U_{j}$ for each attribute can be measured by the following formula (Gershon, 1984):

$U_{j}=\prod_{i=1}^{n}\left|x_{i j}-x_{i}^{-}\right|^{w_{i}}, j=1,2, \ldots, m$,

where $w_{i}$ is the importance weight for each attribute. After calculating the utility values, the most preferable alternative can then be defined as the one with the greatest utility; the result is given by ranking the values in descending order. However, due to the fact that multiplying any value by 0 equals 0 , using CGT will automatically screen out all the alternatives that carry at least one worst impact value. Even if those alternatives might result in better outcomes (impacts) in other attributes, they still will not be considered.

\section{(d) Technique for order preference by similarity to ideal solution (TOPSIS)}

TOPSIS is a technique that was developed by Hwang and Yoon (1981). They explain that a MADM problem may be viewed as a geometric system. The $m$ alternatives that are evaluated by $n$ attributes are similar to $m$ points in the $n$ dimensional space. Therefore, the most preferable alternative should satisfy a condition such that it has the "shortest distance" from the positive-ideal solution and the "longest distance" from the negative-ideal solution.

\subsubsection{Ranking result aggregation}

Due to the different characteristics of the four MADM methods, the outcomes from applying them to solve a decisionmaking problem might be diverse. If the diversity is small, then the outcome is considered reliable. If the outcomes are inconsistent, further aggregations have to be done. Different approaches of MADM aggregation were adopted in this paper, including:

\section{(a) Average ranking procedure}

The average ranking procedure is the simplest technique among the three aggregation methods. This technique is based on the concept of statistical calculation and ranks the alternatives according to the average rankings from the MADM methods.

\section{(b) Borda method}

It is based on the concept of voting and it compares each pair of alternatives separately and forms an $N \times N$ matrix. For each pair of alternatives $A_{j}$ and $A_{j^{\prime}}$, the number of votes is 
defined as the number of "supporting" methods in which $A_{j}$ is more preferable than $A_{j^{\prime}}$. Then an $N \times N$ matrix $X$ is generated such that $x_{j j^{\prime}}=1$, if $A_{j}$ receives more votes than $A_{j^{\prime}}$, $x_{j j^{\prime}}=0$, otherwise. $S_{j}$ indicates the number of "wins" that $A_{j}$ has received against other alternatives and it is calculated by summing the $x_{j j^{\prime}}$ in each row of the matrix. Hence, the alternative with the highest $S_{j}$ is considered the most preferable.

\section{(c) Copeland method}

This is an extension of the Borda method, which is also based on the voting concept. It is believed that the aggregation utility of $A_{j}$ does not only depend on the number of "wins", but the number of "losses" also needs to be taken into account. The number of "losses", denoted as $S_{j^{\prime}}$, is used to compensate the utility value of $S_{j} . S_{j^{\prime}}$ is calculated by summing the values of each column of the matrix and the aggregation utility is simply defined as the difference of $S_{j}$ from $S_{j^{\prime}}$. As with the Borda method, the Copeland method ranks the alternatives in descending order of their aggregation utilities from largest to smallest. Although using these aggregation methods may still result in inconsistencies among the rankings, some useful patterns can easily be observed by the decisionmaker according to the analyzed information.

\section{Results}

\subsection{Indicator value of nine provinces in the Yellow River basin}

First, the $D_{33}$ indicator -"perfection degree of management system and legal system", which involves the fuzzy data - was transformed into numeric data by applying the conversion scale, including five terms (see Fig. 3). The indicator refers to the five terms as "absolute good", "good", "medium", "poor" and "absolute poor", which correspond to the selected scale involving "high", "medium high", "medium", "medium low" and "low". Thus, the membership functions of $M_{1}, M_{2}, M_{3}, M_{4}$ and $M_{5}$ can be presented as

$$
\begin{aligned}
& \mu_{M_{1}}(x)=-\frac{1}{0.3} x+1, \quad 0 \leq x \leq 0.3 \\
& \mu_{M_{2}}(x)=\left\{\begin{array}{lc}
\frac{1}{0.25} x & 0 \leq x<0.25 \\
-\frac{1 .}{0.25} x+2 & 0.25 \leq x<0.5
\end{array},\right. \\
& \mu_{M_{3}}(x)=\left\{\begin{array}{ll}
\frac{1}{0.2} x-\frac{3}{2} & 0.3 \leq x<0.5 \\
-\frac{1}{0.2} x+\frac{7}{2} & 0.5 \leq x<0.7
\end{array},\right. \\
& \mu_{M_{4}}(x)=\left\{\begin{array}{ll}
\frac{1}{0.25} x-2 & 0.5 \leq x<0.75 \\
-\frac{1}{0.25} x+4 & 0.75 \leq x<1
\end{array}\right. \text {, } \\
& \mu_{M_{5}}(x)=\frac{1}{0.3} x-\frac{7}{3}, \quad 0.75 \leq x \leq 1 .
\end{aligned}
$$

Table 4. Determination of $\mu_{\text {total }}$.

\begin{tabular}{cccc}
\hline$i$ & $\mu_{R}\left(M_{i}\right)$ & $\mu_{L}\left(M_{i}\right)$ & $\mu_{T}\left(M_{i}\right)$ \\
\hline 1 & 0.2308 & 1.0000 & 0.1154 \\
2 & 0.6667 & 0.8000 & 0.4334 \\
3 & 0.5833 & 0.5833 & 0.5000 \\
4 & 0.8000 & 0.4000 & 0.7000 \\
5 & 1.0000 & 0.2308 & 0.8846 \\
\hline
\end{tabular}

Using Eqs. (3)-(5), the total utility scores were calculated and the set of $\mu_{\text {total }}$ can substitute the original linguistic terms, which are shown in Table 4. Hence, "absolute good", "good", "medium", "poor" and "absolute poor" were replaced with the values: $0.8846,0.7000,0.5000,0.4333$ and 0.1154 .

Water resources security in the Yellow River basin is in the middle and the lower level in China, so there is no need to add the four standard samples $\left(A_{a}, A_{b}, A_{c}\right.$ and $\left.A_{d}\right)$ in order to simplify the calculation process. Therefore, 18 alternatives were determined in the evaluation, including the 9 provinces alternatives and 9 criteria alternatives. The values of the 18 alternatives are shown in Tables 5 and 6.

\subsection{MADM ranking results}

After the evaluation indicator system was established, the values of indicators were normalized by using Eqs. (8)-(9). Hence, the ranking results were obtained under the four MADM methods. By using Eq. (11), the SWA ranking results are $A e l,>A f>$ Sichuan $>A g>$ Henan $>A h>$ Shandong $>$ Qinghai $>A i>$ Shaanxi $>A j>$ Gansu $>$ Shanxi $>A k>$ Inner Mongolia $>A l>A m>$ Ningxia. By using Eq. (12), the WP ranking results are Qinghai $>$ Sichuan $>$ Gansu $>A e>$ Shandong $>A f>A g>A h>$ Inner Mongolia $>$ Henan $>$ Shaanxi $>A i>A j>A k>$ Shanxil $>A l>A m$ $>$ Ningxia. It is worth noting that when the negative indicator equals 0 , its negative power does not make sense. Therefore, in order to rank all the provinces in the basin and the standard alternatives, we used 0.00001 to replace the indicator which equals 0 and the influence on the results can be ignored. By using Eq. (14), the CGT ranking results are $A e>A f>A g>A h>$ Henan $>A i>A j>$ Shaanxi $>A k>A l$ $>$ Gansu $>$ Shandong $>$ Qinghai $>A m>$ Inner Mongolia $>$ Shanxi $>$ Sichuan $>$ Ningxia. Specifically, $U_{j}$ is 0 when the alternative includes at least one indicator that was selected to be the worst sample, which is not conducive to rank all the alternatives. Under this consideration, the positive indicator in the worst sample was decreased by 0.00001 , and the negative indicator was increased by 0.00001 during the data processing. By using TOPSIS, the ranking results are Sichuan $>A e>A f>$ Qinghai $>$ Henan $>A g>A h>$ Shaanxi $>$ Gansu $>$ Shandong $>A i>$ Shanxi $>A j>A k>$ Inner Mongolia $>A l>A m>$ Ningxia. 
Table 5. Indicator value of nine provinces in the water resources security evaluation system in the Yellow River basin.

\begin{tabular}{|c|c|c|c|c|c|c|c|c|c|}
\hline Indicator & $\begin{array}{r}A_{1} \\
\text { Qinghai }\end{array}$ & $\begin{array}{r}A_{2} \\
\text { Sichuan }\end{array}$ & $\begin{array}{r}A_{3} \\
\text { Gansu }\end{array}$ & $\begin{array}{r}A_{4} \\
\text { Ningxia }\end{array}$ & $\begin{array}{r}A_{5} \\
\text { Inner } \\
\text { Mongolia }\end{array}$ & $\begin{array}{r}A_{6} \\
\text { Shaanxi }\end{array}$ & $\begin{array}{r}A_{7} \\
\text { Shanxi }\end{array}$ & $\begin{array}{r}A_{8} \\
\text { Henan }\end{array}$ & $\begin{array}{r}A 9 \\
\text { Shandong }\end{array}$ \\
\hline D1 & 0.28 & 0.30 & 0.15 & 0.08 & 0.13 & 0.14 & 0.11 & 0.25 & 0.21 \\
\hline D2 & 114.73 & 164.59 & 63.19 & 16.01 & 9.18 & 47.74 & 31.51 & 105.51 & 78.31 \\
\hline D3 & 0.08 & 0.00 & 0.28 & 0.46 & 1.88 & 1.91 & 2.43 & 4.63 & 5.04 \\
\hline D4 & 11.55 & 16.46 & 6.60 & 2.06 & 2.80 & 6.68 & 5.58 & 15.18 & 12.88 \\
\hline D5 & 0.12 & 0.01 & 0.46 & 7.46 & 2.32 & 0.70 & 0.74 & 1.01 & 1.13 \\
\hline D6 & 9.28 & 0.79 & 42.58 & 908.40 & 533.79 & 49.62 & 48.21 & 105.96 & 763.57 \\
\hline D7 & 339.02 & 100.00 & 163.19 & 212.30 & 85.95 & 122.89 & 108.92 & 177.87 & 150.58 \\
\hline D8 & 441.77 & 134.08 & 304.19 & 1128.89 & 353.94 & 195.75 & 133.50 & 185.66 & 153.68 \\
\hline D9 & 312.00 & 182.00 & 235.00 & 228.00 & 84.00 & 92.00 & 67.00 & 101.00 & 71.00 \\
\hline D10 & 0.05 & 0.00 & 0.17 & 2.44 & 2.16 & 0.75 & 0.96 & 0.46 & 1.32 \\
\hline D11 & 0.00 & 0.00 & 0.00 & 0.97 & 0.00 & 0.07 & 2.19 & 1.16 & 0.00 \\
\hline D12 & 1.11 & 0.71 & 1.18 & 1.14 & 1.09 & 1.24 & 1.41 & 0.97 & 1.13 \\
\hline D13 & 3900.74 & 31123.47 & 518.24 & 175.58 & 496.71 & 312.89 & 245.96 & 321.24 & 218.17 \\
\hline D14 & 1.34 & 0.14 & 3.08 & 15.53 & 6.52 & 4.71 & 4.16 & 15.65 & 14.58 \\
\hline D15 & 451.99 & 266.96 & 242.26 & 1321.36 & 1156.91 & 220.68 & 183.56 & 331.21 & 247.08 \\
\hline D16 & 1.02 & 1.99 & 0.80 & 1.17 & 3.27 & 1.13 & 1.38 & 1.78 & 1.61 \\
\hline D17 & 76.02 & 83.33 & 58.56 & 90.19 & 87.16 & 61.42 & 59.82 & 69.56 & 57.59 \\
\hline D18 & 68.63 & 60.95 & 63.88 & 69.40 & 80.83 & 75.58 & 66.69 & 73.35 & 75.78 \\
\hline D19 & 0.29 & 0.00 & 0.91 & 0.86 & 0.56 & 1.15 & 0.69 & 1.59 & 0.61 \\
\hline D20 & 15.27 & 21.18 & 58.44 & 74.81 & 82.86 & 66.30 & 78.12 & 54.05 & 52.20 \\
\hline D21 & 78.00 & 50.00 & 55.00 & 37.00 & 43.80 & 47.10 & 34.00 & 48.20 & 27.60 \\
\hline D22 & 90.50 & 58.40 & 59.90 & 54.00 & 38.20 & 41.80 & 32.20 & 44.10 & 20.00 \\
\hline D23 & 94.00 & 100.00 & 44.83 & 61.34 & 49.95 & 79.14 & 17.28 & 18.80 & 6.06 \\
\hline D24 & 5.09 & 0.18 & 2.38 & 2.89 & 0.47 & 1.29 & 2.65 & 1.82 & 0.50 \\
\hline D25 & 57.00 & 65.00 & 45.00 & 55.00 & 58.00 & 60.00 & 76.00 & 72.00 & 70.00 \\
\hline D26 & 38.47 & 2.14 & 16.34 & 40.53 & 60.19 & 41.93 & 34.15 & 59.49 & 87.71 \\
\hline D27 & 0.38 & 0.46 & 0.47 & 0.34 & 0.44 & 0.57 & 0.60 & 0.55 & 0.62 \\
\hline D28 & 27.90 & 0.00 & 46.80 & 30.97 & 42.84 & 54.61 & 68.67 & 34.89 & 46.00 \\
\hline D29 & 13.50 & 18.70 & 17.80 & 22.00 & 16.30 & 19.00 & 15.60 & 18.00 & 20.00 \\
\hline D30 & 36.30 & 22.00 & 45.50 & 22.40 & 55.10 & 60.30 & 50.10 & 53.50 & 55.00 \\
\hline D31 & 96.00 & 100.00 & 89.00 & 96.00 & 54.00 & 94.00 & 86.00 & 90.00 & 100.00 \\
\hline D32 & 54.13 & 64.88 & 58.54 & 44.37 & 58.27 & 60.92 & 46.75 & 60.81 & 70.87 \\
\hline D33 & 0.70 & 0.70 & 0.50 & 0.43 & 0.43 & 0.50 & 0.50 & 0.50 & 0.50 \\
\hline
\end{tabular}

\subsection{MADM aggregation results}

The alternatives were ranked according to the mean rankings from the four MADM methods, which are shown in Table 7.

According to average ranking procedure, the final ranking order is $A e>A f>A g>$ Sichuan $>A h$, Henan $>$ Qinghai $>$ Shandong $>$ Gansu $>$ Shaanxi $>A i>A j$ $>A k>$ Inner Mongolia $>$ Shanxi $>A l>A m>$ Ningxia. According to Borda, each pair of alternatives were compared separately and the $N \times N$ matrix $X$ was formed, which is shown in Table 8. According to the value of $S_{j}$, the final ranking order is $A e>A f>$ Sichuan $>A g>A h$, Henan $>$ Qinghai $>$ Shaanxi, Shandong $>A i, \quad$ Gansu $>A j>A k>$ Shanxi, and Inner Mongolia $>A l>A m>$ Ningxia. For the Copeland method, according to the value of $S_{j}-S_{j^{\prime}}$, the final ranking order is $A e>A f$, Sichuan $>A g>$ Qinghai $>A h$, Henan $>$ Shaanxi,
Shandong $>A i$, Gansu $>A j>A k>$ Shanxi $>$ Inner Mongolia $>A l>A m>$ Ningxia.

Based on the ranking results of the three aggregation methods, the water resources security degrees of the nine provinces in the Yellow River basin are shown in Table 9. Copeland aggregation results are shown in Fig. 4 and Table 10.

Among the nine provinces in the Yellow River basin, water resources security evaluation conditions are relatively poor in Shanxi, Inner Mongolia and Ningxia province. Ranking results of the 33 indicator values are included in Table 11.

\section{Discussions}

In the four MADM methods in FMADAA, CGT ranking results are significantly different to the other three methods. 
Table 6. Indicator value of nine standards in the water resources security evaluation system in the Yellow River basin.

\begin{tabular}{|c|c|c|c|c|c|c|c|c|c|}
\hline Indicator & $A_{e}$ & $A_{f}$ & $A_{g}$ & $A_{h}$ & $A_{i}$ & $A_{j}$ & $A_{k}$ & $A_{l}$ & $A_{m}$ \\
\hline D1 & 0.22 & 0.21 & 0.20 & 0.18 & 0.17 & 0.16 & 0.15 & 0.13 & 0.12 \\
\hline D2 & 80.00 & 71.25 & 62.50 & 53.75 & 45.00 & 36.25 & 27.50 & 18.75 & 10.00 \\
\hline D3 & 4.00 & 3.63 & 3.25 & 2.88 & 2.50 & 2.13 & 1.75 & 1.38 & 1.00 \\
\hline D4 & 35.00 & 31.25 & 27.50 & 23.75 & 20.00 & 16.25 & 12.50 & 8.75 & 5.00 \\
\hline D5 & 2.00 & 2.25 & 2.50 & 2.75 & 3.00 & 3.25 & 3.50 & 3.75 & 4.00 \\
\hline D6 & 50.00 & 55.00 & 60.00 & 65.00 & 70.00 & 75.00 & 80.00 & 85.00 & 90.00 \\
\hline D7 & 50.00 & 55.00 & 60.00 & 65.00 & 70.00 & 75.00 & 80.00 & 85.00 & 90.00 \\
\hline D8 & 200.00 & 220.00 & 240.00 & 260.00 & 280.00 & 300.00 & 320.00 & 340.00 & 360.00 \\
\hline D9 & 65.00 & 71.25 & 77.50 & 83.75 & 90.00 & 96.25 & 102.50 & 108.75 & 115.00 \\
\hline D10 & 0.90 & 1.00 & 1.10 & 1.20 & 1.30 & 1.40 & 1.50 & 1.60 & 1.70 \\
\hline D11 & 0.80 & 0.85 & 0.90 & 0.95 & 1.00 & 1.05 & 1.10 & 1.15 & 1.20 \\
\hline D12 & 1.00 & 1.05 & 1.10 & 1.15 & 1.20 & 1.25 & 1.30 & 1.35 & 1.40 \\
\hline D13 & 750.00 & 712.50 & 675.00 & 637.50 & 600.00 & 562.50 & 525.00 & 487.50 & 450.00 \\
\hline D14 & 12.00 & 11.00 & 10.00 & 9.00 & 8.00 & 7.00 & 6.00 & 5.00 & 4.00 \\
\hline D15 & 600.00 & 550.00 & 500.00 & 450.00 & 400.00 & 350.00 & 300.00 & 250.00 & 200.00 \\
\hline D16 & 1.80 & 1.75 & 1.70 & 1.65 & 1.60 & 1.55 & 1.50 & 1.45 & 1.40 \\
\hline D17 & 65.00 & 67.50 & 70.00 & 72.50 & 75.00 & 77.50 & 80.00 & 82.50 & 85.00 \\
\hline D18 & 125.00 & 118.75 & 112.50 & 106.25 & 100.00 & 93.75 & 87.50 & 81.25 & 75.00 \\
\hline D19 & 2.70 & 2.48 & 2.25 & 2.03 & 1.80 & 1.58 & 1.35 & 1.13 & 0.90 \\
\hline D20 & 35.00 & 40.00 & 45.00 & 50.00 & 55.00 & 60.00 & 65.00 & 70.00 & 75.00 \\
\hline D21 & 65.00 & 61.25 & 57.50 & 53.75 & 50.00 & 46.25 & 42.50 & 38.75 & 35.00 \\
\hline D22 & 65.00 & 61.25 & 57.50 & 53.75 & 50.00 & 46.25 & 42.50 & 38.75 & 35.00 \\
\hline D23 & 60.00 & 56.25 & 52.50 & 48.75 & 45.00 & 41.25 & 37.50 & 33.75 & 30.00 \\
\hline D24 & 4.00 & 3.75 & 3.50 & 3.25 & 3.00 & 2.75 & 2.50 & 2.25 & 2.00 \\
\hline D25 & 75.00 & 72.50 & 70.00 & 67.50 & 65.00 & 62.50 & 60.00 & 57.50 & 55.00 \\
\hline D26 & 70.00 & 67.50 & 65.00 & 62.50 & 60.00 & 57.50 & 55.00 & 52.50 & 50.00 \\
\hline D27 & 0.55 & 0.53 & 0.50 & 0.48 & 0.45 & 0.43 & 0.40 & 0.38 & 0.35 \\
\hline D28 & 75.00 & 71.25 & 67.50 & 63.75 & 60.00 & 56.25 & 52.50 & 48.75 & 45.00 \\
\hline D29 & 13.00 & 13.75 & 14.50 & 15.25 & 16.00 & 16.75 & 17.50 & 18.25 & 19.00 \\
\hline D30 & 55.00 & 52.50 & 50.00 & 47.50 & 45.00 & 42.50 & 40.00 & 37.50 & 35.00 \\
\hline D31 & 96.00 & 95.25 & 94.50 & 93.75 & 93.00 & 92.25 & 91.50 & 90.75 & 90.00 \\
\hline D32 & 75.00 & 72.50 & 70.00 & 67.50 & 65.00 & 62.50 & 60.00 & 57.50 & 55.00 \\
\hline D33 & 0.70 & 0.50 & 0.50 & 0.50 & 0.43 & 0.43 & 0.43 & 0.12 & 0.12 \\
\hline
\end{tabular}

This is because CGT will automatically rule out (or shrink) all the alternatives that contain at least one minimum indicator value of the worst sample although the other indicators are at a higher level in the whole basin. For example, water resources amount is abundant in Sichuan province, and many indicators of the evaluation system are better than the other provinces. However, the three indicator values are 0 , including modulus of groundwater resources, eco-environment water consumption ratio and water-saving irrigation rate, which decreases overall water resources security in Sichuan province.

From Table 9, it can be seen that the ranking order is different from Borda and Copeland. This is because in FMADAA, four MADM methods' impacts on the results of average ranking procedure methods are the same, since they are determined by the mean rankings. Hence, we can see that compared with the Copeland aggregation method, the water resources security condition in Henan province is better than in Qinghai province, which is influenced by the results of the
CGT method. Meanwhile, the condition in Gansu province is better than that in Shaanxi province and the Ai standard alternative because of the impact by the results of the WP method. We can also see that the results of Copeland are a little different from the Borda method as well because it considers both the "wins" and "losses" of the alternatives.

Although the results of the three aggregation methods are not exactly consistent, some certain and useful information can be obtained, such as the ranking order: $A e>A f$, Sichuan, $A g>A h$, Qinghai, Henan $>A i$, Shandong, Shaanxi, Gansu $>A j>A k>$ Shanxi, Inner Mongolia $>A l>A m>$ Ningxia. The water resources security in these provinces is in a critical state, including Sichuan, Qinghai and Henan. Shanxi and Inner Mongolia are in the insecurity state. Meanwhile, Ningxia province is in the absolute insecurity state. Shandong, Shaanxi and Gansu provinces are in the critical or insecurity state.

As to the ranking order of one province, because it is based on a voting principle, the Copeland method will 


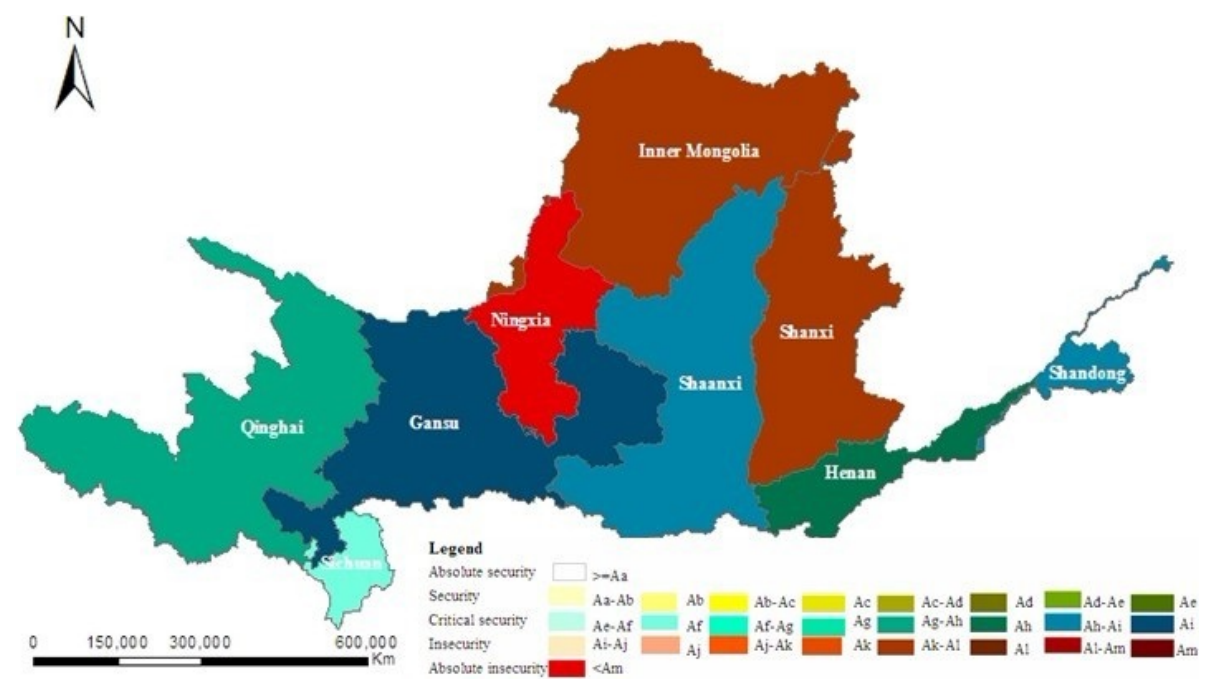

Fig. 4. Copeland aggregation results in the nine provinces.

Table 7. Summary of indicator values in average ranking procedure.

\begin{tabular}{lrrrrr}
\hline & \multicolumn{3}{c}{ MADM methods } & Mean \\
\cline { 2 - 4 } & M1 & M2 & M3 & M4 & rankings \\
\hline$A_{1}$ Qinghai & 11 & 18 & 6 & 15 & 12.50 \\
$A_{2}$ Sichuan & 16 & 17 & 2 & 18 & 13.25 \\
$A_{3}$ Gansu & 7 & 16 & 8 & 10 & 10.25 \\
$A_{4}$ Ningxia & 1 & 1 & 1 & 1 & 1.00 \\
$A_{5}$ Inner Mongolia & 4 & 10 & 4 & 4 & 5.50 \\
$A_{6}$ Shaanxi & 9 & 8 & 11 & 11 & 9.75 \\
$A_{7}$ Shanxi & 6 & 4 & 3 & 7 & 5.00 \\
$A_{8}$ Henan & 14 & 9 & 14 & 14 & 12.75 \\
$A_{9}$ Shandong & 12 & 14 & 7 & 9 & 10.50 \\
$A_{e}$ & 18 & 15 & 18 & 17 & 17.00 \\
$A_{f}$ & 17 & 13 & 17 & 16 & 15.75 \\
$A_{g}$ & 15 & 12 & 16 & 13 & 14.00 \\
$A_{h}$ & 13 & 11 & 15 & 12 & 12.75 \\
$A_{i}$ & 10 & 7 & 13 & 8 & 9.50 \\
$A_{j}$ & 8 & 6 & 12 & 6 & 8.00 \\
$A_{k}$ & 5 & 5 & 10 & 5 & 6.25 \\
$A_{l}$ & 3 & 3 & 9 & 3 & 4.50 \\
$A_{m}$ & 2 & 2 & 5 & 2 & 2.75 \\
\hline
\end{tabular}

rule out the influence of the large difference of evaluation results between one MADM method and the others. Besides, it considers both the "wins" and "losses" of the alternatives, so to some extent, it is more reasonable. The ranking order by using the Copeland method is $A e>A f$, Sichuan $>A g>$ Qinghai $>A h$, Henan $>$ Shaanxi, Shandong $>A i$, Gansu $>A j>A k>$ Shanxi $>$ Inner Mongolia $>A l>A m>$ Ningxia. From the results shown in Fig. 4 and Table 10, we can see that the water resources security of the whole basin is in critical, insecurity and absolute insecurity states, which is at the lower level in China. The provinces whose water resources security is in a critical state include Sichuan, Qinghai, Henan, Shanxi, Shandong and Gansu. Shanxi and Inner Mongolia are in the insecurity state. Meanwhile, Ningxia province is in the absolute insecurity state.

For the regional distribution, we can see that water resources security of the provinces located upstream of the Yellow River is better than the other provinces such as Qinghai and Sichuan province. The southern provinces are better than the northern provinces such as Sichuan province. Meanwhile, the developed provinces are better than the other provinces such as Sichuan, Shandong and Henan province. This is because the amount of water resources that is relatively abundant in the upstream and the values of socio-economicrelated indicators are higher in the developed provinces, which enhance its whole water resources security.

Among the nine provinces in the Yellow River basin, water resources security conditions are relatively poor in Shanxi, Inner Mongolia and Ningxia province. From Table 11 we can see that the indicator values of the water resources pressure system are smaller in the three provinces, which means that in the pressure system, water resources pressure is relatively high in the three provinces. Meanwhile, the indicator values' ranking results in water resources state and water eco-environment state of state system, and socio-economic response system are the worst in Shanxi province. It can be seen that the higher water resources pressure, the worse water resources and water eco-environment state, and the backward responses result in insecure water resources in Shanxi province. Similarly, the higher water resources and socio-economic pressure and worse water eco-environment state result in insecure water resources in Inner Mongolia province. Water resources have absolute insecurity in Ningxia province because of the higher pressure in water 
Table 8. $N \times N$ matrix used in the Borda and Copeland methods.

\begin{tabular}{lccccccccccccccccccc}
\hline & & $A_{2}$ & $A_{3}$ & $A_{4}$ & $A_{5}$ & $A_{6}$ & $A_{7}$ & $A_{8}$ & $A_{9}$ & $A_{e}$ & $A_{f}$ & $A_{g}$ & $A_{h}$ & $A_{i}$ & $A_{j}$ & $A_{k}$ & $A_{l}$ & $A_{m}$ & $S_{j}$ \\
\hline$A_{1}$ & 0 & 0 & 1 & 1 & 1 & 1 & 1 & 0 & 0 & 0 & 0 & 0 & 0 & 1 & 1 & 1 & 1 & 1 & 10 \\
$A_{2}$ & 0 & 0 & 1 & 1 & 1 & 1 & 1 & 1 & 1 & 0 & 0 & 1 & 1 & 1 & 1 & 1 & 1 & 1 & 14 \\
$A_{3}$ & 0 & 0 & 0 & 1 & 1 & 0 & 1 & 0 & 1 & 0 & 0 & 0 & 0 & 0 & 0 & 1 & 1 & 1 & 7 \\
$A_{4}$ & 0 & 0 & 0 & 0 & 0 & 0 & 0 & 0 & 0 & 0 & 0 & 0 & 0 & 0 & 0 & 0 & 0 & 0 & 0 \\
$A_{5}$ & 0 & 0 & 0 & 1 & 0 & 0 & 0 & 0 & 0 & 0 & 0 & 0 & 0 & 0 & 0 & 0 & 1 & 1 & 3 \\
$A_{6}$ & 0 & 0 & 1 & 1 & 1 & 0 & 1 & 0 & 0 & 0 & 0 & 0 & 0 & 0 & 1 & 1 & 1 & 1 & 8 \\
$A_{7}$ & 0 & 0 & 0 & 1 & 0 & 0 & 0 & 0 & 0 & 0 & 0 & 0 & 0 & 0 & 0 & 0 & 1 & 1 & 3 \\
$A_{8}$ & 0 & 0 & 1 & 1 & 1 & 1 & 1 & 0 & 1 & 0 & 0 & 0 & 0 & 1 & 1 & 1 & 1 & 1 & 11 \\
$A_{9}$ & 0 & 0 & 0 & 1 & 1 & 0 & 1 & 0 & 0 & 0 & 0 & 0 & 0 & 1 & 1 & 1 & 1 & 1 & 8 \\
$A_{e}$ & 1 & 0 & 1 & 1 & 1 & 1 & 1 & 1 & 1 & 0 & 1 & 1 & 1 & 1 & 1 & 1 & 1 & 1 & 16 \\
$A_{f}$ & 1 & 0 & 1 & 1 & 1 & 1 & 1 & 1 & 1 & 0 & 0 & 1 & 1 & 1 & 1 & 1 & 1 & 1 & 15 \\
$A_{g}$ & 0 & 0 & 1 & 1 & 1 & 1 & 1 & 1 & 1 & 0 & 0 & 0 & 1 & 1 & 1 & 1 & 1 & 1 & 13 \\
$A_{h}$ & 0 & 0 & 1 & 1 & 1 & 1 & 1 & 0 & 1 & 0 & 0 & 0 & 0 & 1 & 1 & 1 & 1 & 1 & 11 \\
$A_{i}$ & 0 & 0 & 0 & 1 & 1 & 0 & 1 & 0 & 0 & 0 & 0 & 0 & 0 & 0 & 1 & 1 & 1 & 1 & 7 \\
$A_{j}$ & 0 & 0 & 0 & 1 & 1 & 0 & 1 & 0 & 0 & 0 & 0 & 0 & 0 & 0 & 0 & 1 & 1 & 1 & 6 \\
$A_{k}$ & 0 & 0 & 0 & 1 & 1 & 0 & 0 & 0 & 0 & 0 & 0 & 0 & 0 & 0 & 0 & 0 & 1 & 1 & 4 \\
$A_{l}$ & 0 & 0 & 0 & 1 & 0 & 0 & 0 & 0 & 0 & 0 & 0 & 0 & 0 & 0 & 0 & 0 & 0 & 1 & 2 \\
$A_{m}$ & 0 & 0 & 0 & 1 & 0 & 0 & 0 & 0 & 0 & 0 & 0 & 0 & 0 & 0 & 0 & 0 & 0 & 0 & 1 \\
$S_{j}^{\prime}$ & 2 & 0 & 8 & 17 & 13 & 7 & 12 & 4 & 7 & 0 & 1 & 3 & 4 & 8 & 10 & 12 & 15 & 16 & -15 \\
$S_{j-}^{\prime} S_{j}^{\prime}$ & 8 & 14 & -1 & -17 & -10 & 1 & -9 & 7 & 1 & 16 & 14 & 10 & 7 & -1 & -4 & -8 & -13 & -15 \\
\hline
\end{tabular}

resources, socio-economic, and water environment system and backward socio-economic responses.

Therefore, the future planning of the Yellow River basin should focus on soil erosion management, and improvement of water quality in water function areas, rivers and groundwater in order to improve the water eco-environment status in Shanxi and Inner Mongolia province. Meanwhile, the water utilization efficiency should be improved so that the socio-economic pressure is decreased and water management should be enhanced, such as increasing the water conservancy investment, industrial and agricultural water-saving intensity and the rural population access to up-to-standard drinking water. In addition, it is also important to raise the water supply capacity in Shanxi province in order to improve the water resources status as well as to enhance the control of sewage disposal in Ningxia province so that the water environment pressure can be decreased.

In summary, FMADAA can be successfully applied in water resources security evaluation in the Yellow River basin because it is a combination of fuzzy and different MADM methods; it also aggregates various results of MADM methods, which can provide a more rational result. In addition, the system can also deal with fuzzy information usually encountered in practical evaluation processes. The ranking results showed that the water resources security of the whole Yellow River basin is in critical, insecurity and absolute insecurity states, which is at the lower level in China, especially in Shanxi, Inner Mongolia and Ningxia provinces, whose water resources are in insecurity and absolute insecurity states. Hence, future planning of the Yellow River basin should focus on these three provinces in order to promote the overall water resources security and to guarantee coordinated development in the basin.

\section{Conclusions}

Through introducing the concept of water resources security, a "pressure-state-response" water resources security evaluation system was developed in this research. Multiple-level indicators were identified within the system. Also, a fuzzy multi-attribute decision analysis approach (FMADAA) was proposed not only for dealing with the evaluation based on the developed indicators, but also for tackling the inherent uncertainties. As for the ranking order of alternatives under different methods, Copeland aggregation was adopted. The evaluation system was then applied to the Yellow River basin. The results showed that the water resources security of the basin was in critical, insecurity and absolute insecurity states. The provinces whose water resources security was in the critical state included Sichuan, Qinghai, Henan, Shanxi, Shandong and Gansu. Shanxi and Inner Mongolia were in the insecurity state. Meanwhile, Ningxia province is in the absolute insecurity state. For regional distribution, water resources security of the provinces located upstream of the Yellow River was better than other provinces, such as in Qinghai and Sichuan province. The southern provinces were better than northern provinces such as Sichuan province. Normally, provinces with higher economic productivities were better than other provinces such as in Sichuan, Shandong and Henan province. This is because water resources amount 
Table 9. Evaluation level of water resources security by three MADM aggregation methods in nine provinces in 2006.

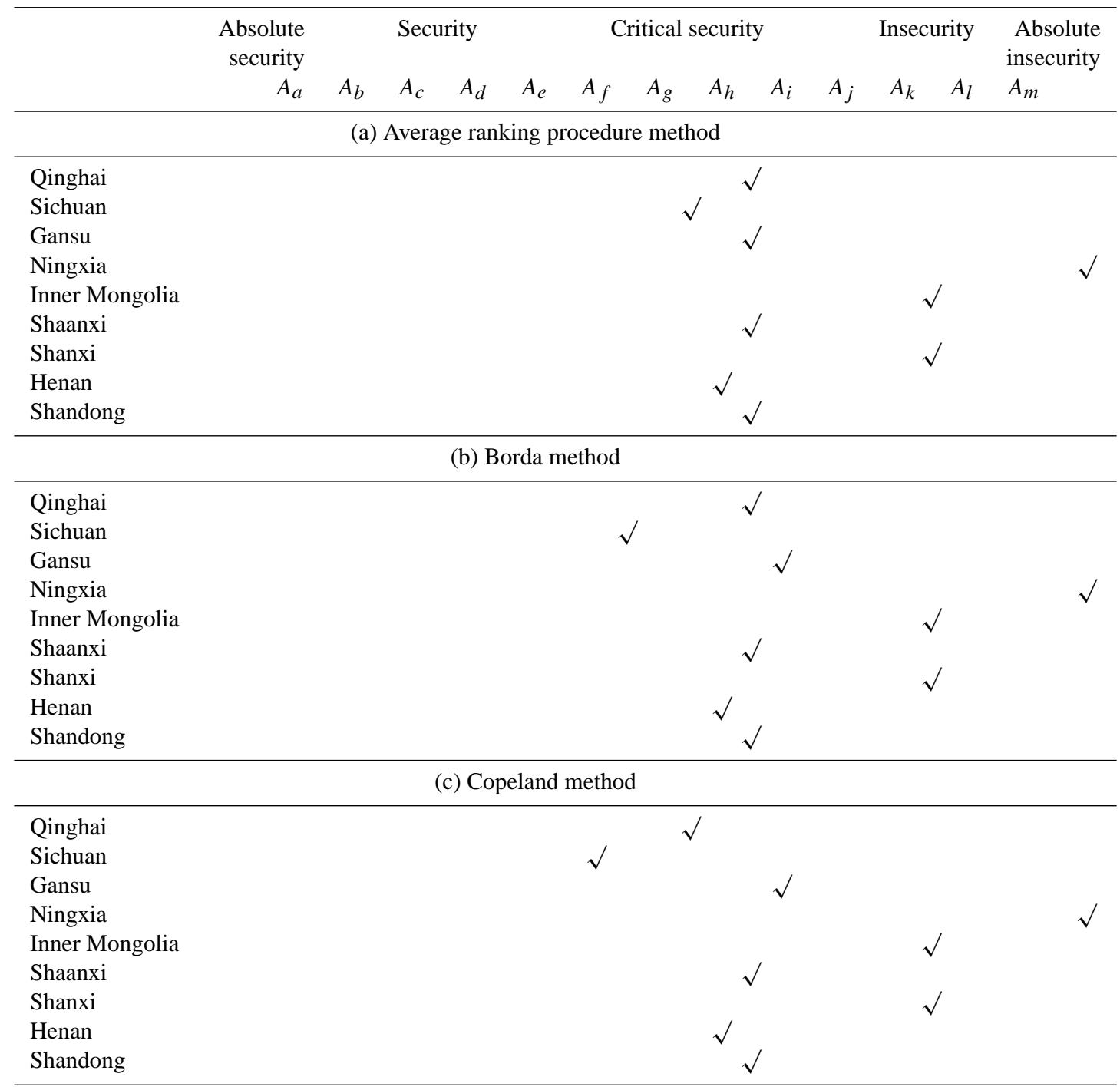

Table 10. Water resources security levels in administrative regions in the Yellow River basin under the Copeland aggregation method (in 2006).

\begin{tabular}{|c|c|c|c|c|c|}
\hline & \multicolumn{5}{|c|}{ Security level } \\
\hline & $\begin{array}{l}\text { Absolute } \\
\text { security }\end{array}$ & Security & Critical security & Insecurity & $\begin{array}{l}\text { Absolute } \\
\text { insecurity }\end{array}$ \\
\hline Provinces & & & $\begin{array}{l}\text { Sichuan, Qinghai, } \\
\text { Henan, Shaanxi and } \\
\text { Shandong, Gansu }\end{array}$ & $\begin{array}{l}\text { Shanxi and } \\
\text { Inner } \\
\text { Mongolia }\end{array}$ & Ningxia \\
\hline
\end{tabular}


Table 11. Ranking results of indicator values in Shanxi, Inner Mongolia and Ningxia provinces.

\begin{tabular}{|c|c|c|c|c|c|c|}
\hline \multicolumn{4}{|r|}{ Evaluation indicator } & \multirow{2}{*}{$\begin{array}{c}\text { Shanxi } \\
8\end{array}$} & \multirow{2}{*}{$\begin{array}{c}\begin{array}{c}\text { Inner } \\
\text { Mongolia }\end{array} \\
7\end{array}$} & \multirow{2}{*}{$\begin{array}{c}\text { Ningxia } \\
9\end{array}$} \\
\hline Pressure & Water & D1 & Water production coefficient & & & \\
\hline indictors & resources & $\mathrm{D} 2$ & Annual runoff & 7 & 9 & 8 \\
\hline \multirow[t]{9}{*}{ B1 } & pressure & D3 & Modulus of groundwater resources & 3 & 5 & 6 \\
\hline & indicators & D4 & Modulus of water resources & 7 & 8 & 9 \\
\hline & $\mathrm{C} 1$ & D5 & Utilization rate & 5 & 8 & 9 \\
\hline & Socio- & D6 & Development degree of surface water & 4 & 7 & 9 \\
\hline & economic & D7 & Development degree of groundwater & 1 & 3 & 8 \\
\hline & pressure & D8 & Water consumption per 10000 Yuan of GDP & 1 & 7 & 9 \\
\hline & $\begin{array}{l}\text { indicators } \\
\mathrm{C} 2\end{array}$ & D9 & Water consumption per 10000 Yuan of industrial output & 1 & 3 & 7 \\
\hline & Water & D10 & Ratio of pollutants (COD and ammonia nitrogen) dumped into the river & 6 & 8 & 9 \\
\hline & $\begin{array}{l}\text { environment } \\
\text { pressure } \\
\text { indicators } \\
\text { C3 }\end{array}$ & D11 & Area ratio of excessive extraction of groundwater & 9 & 2 & 7 \\
\hline \multirow{12}{*}{$\begin{array}{l}\text { State } \\
\text { indictors } \\
\text { B2 }\end{array}$} & Water & D12 & Index of water resources demand-supply balance (IWDS) & 9 & 3 & 6 \\
\hline & $\begin{array}{l}\text { resources } \\
\text { state } \\
\text { indicators } \\
\text { C4 }\end{array}$ & D13 & Water resources amount per capita & 7 & 4 & 9 \\
\hline & Socio- & D14 & Water consumption modulus & 6 & 4 & 2 \\
\hline & economic & D15 & Water supply amount per capita & 9 & 2 & 1 \\
\hline & state & D16 & GDP per capita & 5 & 1 & 6 \\
\hline & indicators & D17 & Agricultural water consumption ratio & 3 & 8 & 9 \\
\hline & C5 & D18 & Domestic water consumption per capita & 7 & 1 & 4 \\
\hline & Water eco- & D19 & Eco-environment water consumption ratio & 5 & 7 & 4 \\
\hline & environment & D20 & Ratio of soil erosion area to the total area & 8 & 9 & 7 \\
\hline & state & D21 & Up-to-standard rate of water quality in water function area & 8 & 6 & 7 \\
\hline & indicators & D22 & Ratio of up-to-standard river length of water quality to the total river length & 8 & 7 & 4 \\
\hline & C6 & D23 & Ratio of class I, II and III groundwater area of water quality to the total area & 8 & 5 & 4 \\
\hline \multirow{10}{*}{$\begin{array}{l}\text { Response } \\
\text { indictors } \\
\text { B3 }\end{array}$} & Socio- & D24 & Water conservancy investment rate & 7 & 2 & 8 \\
\hline & economic & D25 & Industrial water re-utilization rate & 1 & 6 & 8 \\
\hline & response & D26 & Effective irrigation coverage rate & 7 & 2 & 5 \\
\hline & indicators & D27 & Water irrigation efficiency & 8 & 3 & 1 \\
\hline & $\mathrm{C} 7$ & D28 & Water-saving irrigation rate & 1 & 5 & 7 \\
\hline & & D29 & Leakage rate of water supply pipe network & 2 & 3 & 9 \\
\hline & & D30 & Water-saving appliances penetration rate & 5 & 2 & 8 \\
\hline & & D31 & Ratio of urban population access to up-to-standard drinking water to the total urban population & 8 & 9 & 4 \\
\hline & & D32 & Ratio of rural population access to up-to-standard drinking water to the total rural population & 8 & 6 & 9 \\
\hline & & D33 & Perfection degree of management system and legal system & 5 & 8 & 9 \\
\hline
\end{tabular}

was relatively abundant in the upstream and the values of socio-economic related indicators were higher in the developed provinces. Since the water resources security in Shanxi, Inner Mongolia and Ningxia was the worst in the basin, future planning and management should focus on water management in these three provinces.

Acknowledgements. This paper was sponsored by the National Basic Research Program (973 Program) (2010CB951104), the National Science Foundation for Innovative Research Group (No. 51121003), International Science \& Technology Cooperation Program of China 2011DFA72420 and the special fund of State Key Lab of Water Environment Simulation (11Z01ESPCN).

Edited by: Y. Cai

\section{References}

Ana, C. C., John, W. L., and Darrell, G. F.: Multicriteria decision support system for regionalization of integrated water resource management, Water Resour. Manage., 11, 1-22, 2012.

Bass, S. M. and Kwakemaak, H.: Rating and ranking of multiple aspect alternative using fuzzy sets, Automatica, 3, 47-58, 1977.

Bonissone, P. P.: A fuzzy set based linguistic approach: theory and applications, in: Approximate Reasoning in Decision Analysis, edited by: Gupa, M. M. and Sanchez, E., North-Holland Publishing Company, Amsterdam, 329-339, 1982.

Brown, L. R. and Hilweil, B.: China's water shortage could shake world food security, World Watch, 7, 10-18, 1987.

Buede, D.: Second overvies of the MCDA software market, J. Multi-Attrib. Decis. Anal., 5, 312-216, 1996.

Cai, Y. P., Huang, G. H., Yang, Z. F., Sun, W., and Chen, B.: Investigation of public's perception towards rural sustainable development based on a two-level expert system, Expert Syst. Appl., 36, 8910-8924, 2009. 
Chen, S. H.: Ranking fuzzy numbers with maximizing set and minimizing set, Fuzzy Set Syst., 2, 113-129, 1985.

Chen, S. J.: Water resources security concept and its discussion, China Water Resour., 17, 13-15, 2004.

Chen, S. M.: A new approach to handling fuzzy decision-making problems, IEEE T. Syst. Man. Cyb., 6, 1012-1016, 1988.

Chu, A. T. W., Kalaba, R. E., and Spingarn, K.: A comparison of two methods for determining the weights of belonging to fuzzy sets, J. Optimiz. Theory App., 27, 531-538, 1979.

Cong, X.: Application of fuzzy mathematics in water quality assessment, Northwestern Water Conservancy and Hydropower, 276, 55-57, 2007.

Eom, S. B. and Min, H.: The contributions of multi-attribute decision making to the development of decision support systems subspecialties: an empirical investigation, J. Multi-Attrib. Decis. Anal., 5, 239-255, 1999.

Gershon, M.: The role of weights and scales in the application of multiobjective decision making, Eur. J. Oper. Res., 15, 244-250, 1984.

Gorge, T. and Mike, S.: Planning against long term water scarcity: a fuzzy multicriteria approach, Water Resour. Manage., 4, 11031129, 2011.

Han, P. Q., Lu, J. X., and Song, S. H.: Fuzzy clustering's application in water quality evaluation, Environ. Sci. Technol., 30, 165-167, 2001.

Harrison, M., Saroj, S., and Kalanithy, V.: Multi-attribute decision analysis: a strategic planning tool for water loss management, Water Resour. Manage., 4, 1-23, 2011.

Hwang, C. L. and Chen, S. J.: Fuzzy Multiple Attribute Decision Making: Methods and Applications, Springer, New York, 1992.

Hwang, C. L. and Yoon, K.: Multiple Attribute Decision Making: Methods and Applications, Springer, New York, 1981.

Jain, R.: Decision making in the presence of fuzzy variables, IEEE T. Syst. Man. Cyb., 6, 698-703, 1976.

Jain, R.: A procedure for multi-aspect decision making using fuzzy sets, Int. J. Syst. Sci., 8, 1-7, 1977.

Jia, S. F. and Zhang, S. F.: Water resources security appraisement of Haihe basin, Prog. Geogr., 4, 379-387, 2003.

Jia, S. F., Zhang, J. Y., and Zhang, S. F.: Regional water resources stress and water resources security appraisement indicators, Prog. Geogr., 6, 538-545, 2002.

Jia, S. F., He, X. W., and Xia, J.: Problems and countermeasures of water resource security of China, Bull. Chin. Acad. Sci., 5, 347-351, 2004.

Jiang, W. L.: Study on water resource safety strategy for China in the 21 st century, Adv. Water Sci., 1, 66-71, 2001.

Li, C. H. and Yang, Z. F.: Natural runoff changes in the Yellow River basin, J. Geogr. Sci., 24, 427-436, 2004.

Li, C. H., Yang, Z. F., and Wang, X.: Trends of Annual natural runoff in the Yellow River basin, Water Int., 4, 447-454, 2004.

Loucks, D. P.: Sustainable Water Resource Management, Water Int., 1, 3-10, 2000.

Nijkamp, P., Rietveld, P., and Voogd, H.: Multicriteria Evaluation in Physical Planning, North-Holland Publishing Company, Amsterdam, 1990.
Parviz, F. and Saeed, F.: A compromise programming model to integrated urban water management, Water Resour. Manage., 6, 1211-1227, 2010.

Saaty, T. L.: A scaling method for priorities in hierarchical structures, J. Math. Psychol., 15, 234-281, 1977.

Shen, N. and Li, C. H.: Evolution characteristics of runoff in Yellow River during recent 500 years, J. Water Resour. Water Eng., 5, 37-40, 2009.

Starr, M. K.: Production Management, Prentice-Hall, Englewood Cliffs, NJ, 1972.

Szidarovszky, F. and Yakowitz, S.: Principles and Procedures of Numerical Analysis, Plenum Press, New York, 1978.

WWAP: World Water Development Report-WWDR, Washington, D.C., 2002.

Xia, J. and Zhang, Y. Y.: Water security in north China and countermeasure to climate change and human activity, Phys. Chem. Earth, 33, 359-363, 2007.

Xia, X. H., Yang, Z. F., and Wu, Y. X.: Incorporation ecoenvironmental water requirements in integrated evaluation of water quality and quantity - a study for the Yellow River, Water Resour. Manage., 6, 1067-1079, 2009.

Yellow River Conservancy Committee of the Ministry of Water Resources (YRCC, MWR): Statistical yearbook of the Yellow River (report), Zhengzhou, China, 2006.

Yellow River Conservancy Committee of the Ministry of Water Resources (YRCC, MWR): Comprehensive Planning in the Yellow River Basin (report), Zhengzhou, China, 2009.

Yellow River Conservancy Committee of the Ministry of Water Resources (YRCC, MWR): Water Resources Comprehensive Planning in the Yellow River Basin (report), Zhengzhou, China, 2009.

Yoon, K. P.: A reconciliation among discrete compromise situations, J. Operat. Res. Soc., 40, 681-686, 1989.

Yoon, K. P. and Hwang, C. L.: Multiple Attribute Decision Making: an Introduction, Sage Publication Inc., Thousand Oaks, California, 1995.

Yu, Y. B., Wang, B. D., Wang, G. L., and Li, W.: Multi-person multiobjective fuzzy decision-making model for reservoir flood control operation, Water Resour. Manage., 2, 111-124, 2004.

Zhang, J. J.: Fuzzy analytic hierarchy process (FAHP), Fuzzy Syst. Math., 2, 80-88, 2000.

Zhang, J. Y.: Impacts evaluation of climate changes on water resources security, China Water Resour., 8, 5-6, 2010.

Zhang, J. Y., Wang, G. Q., Yang, Y., He, R. M., and Liu, J. F.: The possible impacts of climate change on water security in China, Adv. Clim. Change Res., 5, 290-295, 2008.

Zhang, S. F. and Jia, S. F.: Water balance and water security study in the Haihe basin, J. Nat. Resour., 3, 684-691, 2003.

Zhang, X., Xia, J., and Jia, S. F.: Definition of water security its assessment using, Resource Science, 3, 145-149, 2005.

Zheng, T. H.: Discussions on water resources safety and water resources safety warning, China Water Resour., 6, 19-22, 2003.

Zhu, H. Y., Du, S. S., and Gu, Y. Y.: Fuzzy mathematics and its application in surface water quality evaluation - take Fuyang River in Handan for an example, Groundwater, 5, 80-90, 2008. 